\title{
Polarity, Low Tone Spread, and Underspecification in the Kabiye Verb Phrase
}

\author{
David Roberts \\ Independent researcher
}

\begin{abstract}
This autosegmental analysis of Kabiye verbal derivations and inflections demonstrates that tone patterns on adjectives and locative nominalizations are not the underlying forms of verb roots, as claimed by previous researchers, because they are in complementary distribution. Rather, verb roots are analyzed as being underlyingly $/ \mathrm{H}, \mathrm{L} /$, and two additional morphological elements - verbal extensions and TAM prefixes - both reveal a ternary $/ \mathrm{H},-\mathrm{L},-\varnothing /$ contrast. In toneless extensions, this resolves an adjacency issue with regard to polarity of the TAM suffix, while the three floating tonal TAM prefixes either block, pre-empt or permit $L$ tone spread from the subject pronoun onto the stem. The result is an integrated analysis of derivational and inflectional forms that dovetails with a previous analysis of the associative noun phrase.
\end{abstract}

Keywords: Autosegmenal phonology, tonal polarity, tone spread, underspecification, stray erasure, Kabiye, Gur languages

\section{Introduction}

This study provides an integrated autosegmental account (Goldsmith 1976) of tonal processes in the verb phrase of Kabiye, an Eastern Gurunsi Gur language of Togo, in which a single Lexical Phonology model (Kiparsky 1982; Mohanan 1982) will be applied to both derivational and inflectional forms. It is based on a database of 810 verbs extracted from the Kabiye-French dictionary (CLNK 1999) and checked independently with five L1 informants from the canton of Lama.

The paper begins with a survey of the previous literature concerning the four relevant tonal phenomena that will be exemplified in Kabiye: polarity (Section 2.1), underspecification (Section 2.2), spreading (Section 2.3), and stray erasure (Section 2.4). It continues with an overview of Kabiye segmental phonology and morphology (Section 3.1). The tone analysis begins with some generalizations (Section 3.2.1) and spotlights a pervasive post-lexical process (Section 3.2.2). It then identifies the underlying forms of verb roots and their extensions (Section 3.2.3), including a toneless extension that resolves an adjacency issue with regard to TAM suffix polarity (Section 3.2.4). Lexical L tone spread (Section 3.2.5) and stray erasure (Section 3.2.6) are also explained. A Lexical Phonology model (Section 4.1) is then applied to derivational forms (Section 4.2) and inflectional forms (Section 0). The paper ends with a summary of the findings (Section 5).

\footnotetext{
${ }^{1}$ The canton of Lama, a Kabiye-speaking area incorporating the town of Kara, is not to be confused with the Lama language spoken by the Lamba people in Kandè, Défalé and Kadjala.
} 


\section{Previous literature}

2.1 Polarity. Any discussion of the literature on polarity needs to distinguish it from dissimilation. The latter occurs when a morpheme is realized with a tone dissimilar to its own underlying tone in certain environments, such as in Kanuri (Trommer 2005), Sylheti (Gope \& Mahanta 2016), and four Gur languages: Moore (Kenstowicz et al. 1988: 77-90), Lama (Kenstowicz et al. 1988: 90-102), Dagbani (Hyman 1993), and Dagaare (Anttila \& Bodomo 2000).

Polarity, on the other hand, occurs when a morpheme is underlyingly toneless and surfaces with the tone opposite to its immediate environment. In such cases, an analysis gains nothing by arbitrarily choosing one of the tones as the underlying one (cf. Hyman \& Schuh 1974: 100). ${ }^{2}$ Polarity has been reported in a surprisingly diverse range of morphological environments: the Foodo perfective marker (Plunkett 2009: 129), Idaasha object pronouns (Baloubi 2005: 92-93), Kalabari instrumental and comitative morphemes (Harry \& Hyman 2014: 669), the Igbo gerundive prefix (Hyman \& Schuh 1974), the Daza definite suffix (Wolff \& Alidou 1989), Kwanyama verbal prefixes (Halme 2004: 106), and Xitsonga plural markers (Lee 2013: 107-123). In Kabiye, too, we will see that polarity, rather than dissimilation, is the best way to provide a unified tonal account of derivational and inflectional suffixes.

2.2 Underspecification. The term tonal underspecification is employed when at least some TBUs (tone bearing units) in a given language have no underlying tones. Ever since Stevick (1969), it has been common for two-height systems to be analyzed as privative (i.e. $/ \mathrm{H}, \varnothing /$ ), especially when their surface tones display a certain asymmetry: typically, the surface $\mathrm{H}$ tone is distributionally restricted and phonologically active whereas the surface L tone is more widespread and inert (Hyman 2001, 2009). This is the approach taken in Chichewa (Myers 1998), Macuiltianguis Zapotec (Zimmermann 2016), Iñapari (Parker 1999), Anii (Morton 2014) and Tem (Tchagbale 2002).

In other languages with two-height systems, it is not uncommon for researchers to propose ternary accounts (i.e. $/ \mathrm{H}, \mathrm{L}, \varnothing /$ ), where toneless TBUs receive a default $\mathrm{L}$ at some point in the derivation, so $/ \mathrm{L} /$ and $/ \varnothing /$ converge in surface forms (Odden 2019). This is the case in Margi (Pulleyblank 1986), Kimbundu (Carvalho 2014), Kinande (Mutaka 1994), and Munduruku (Picanço 2005). Inkelas (1995) notes a certain resistance to "the dreaded ternary use of a binary feature" (e.g. Kiparsky 1982), but argues that it is necessary "to overcome the fear of ternarity that has dogged phonologists since Stanley (1967)."

McPherson's (2012) ternary account of Tommo So is of particular interest because it restricts underspecification to certain morphological elements, an approach that will find an echo in Kabiye verbal extensions and TAM prefixes. In extensions, the need for a ternary account arises to resolve an issue of interaction between apparently non-adjacent tonal elements (Odden 1994) which is also the case in Giryama (Philippson 1998: 321), Arusa (Levergood 1987: 58ff) and Peñoles Mixtec (Daly \& Hyman 2005: 136-139).

2.3 Spreading. Spreading is a process whereby a given source tone enlarges its domain, either to the right or to the left (Hyman \& Schuh 1974: 88). Kabiye exemplifies both H and L tone spread, but we will focus on the latter here because, while it is extensive in Kabiye, it is less common worldwide (Hyman 2007: 5).

\footnotetext{
${ }^{2}$ For an opposing view, see Schadeberg (1989: 38) who considers that "Tonal polarity is highly unsatisfactory in all frameworks of tonal description...."
} 
Rightwards spreading, which Hyman \& Schuh (1974: 88) call "perseverative" or "progressive", is the most common. A L tone may spread rightward onto the adjacent tone bearing unit as in Kuki-Thaadow (Hyman 2013: 19), Shixing (Chirkova \& Michaud 2009: 547), Chalcatongo Mixtec (Buckley 1991: 169), Yoruba (Akinlabi \& Liberman 2000: 11), Mundabli (Voll 2012: 6, 9-11), and in four Gur languages: Sucite (Garber Kompaoré 1987: 53), Dagbani (Hyman 1993: 5), Mbelime (Melick 2012: 88), and Buli (Schwarz 2001: 121-130). Rightward spreading may also extend further than the adjacent TBU, as in South-eastern Nochixtlán Mixtec (McKendry 2013: 8, 150-1, 160, 162, 193, 279-285), Kalabari (Harry \& Hyman 2014: 669) and Ruwund (Hyman 2001: 248). This kind of spreading is particularly relevant to the Kabiye analysis that follows.

Leftward spreading - or anticipatory, regressive spreading to use Hyman and Schuh's (1974: 88) terminology - is much less common than rightward spreading, but is found in Itunyoso Trique (Dicanio n.d.: 18) and Krio, an English-based creole of Sierra Leone (Finney 2002: 4). As for the fourth logically possible combination, leftward spreading of $\mathrm{L}$ tones to multiple targets, as far as I am aware it is unattested globally, though I invite correction on this point. It is certainly rare, and its dearth is in contrast to leftward spreading of $\mathrm{H}$ tones to multiple targets, which is not that uncommon (e.g. Tiriki, Paster \& Kim 2011: 84).

2.4 Stray erasure. Stray erasure is an end-of-cycle process that eliminates all unassociated elements (Itô 1988; McCarthy 1979; Steriade 1982). For example, in Ayautla and Amuzgo Mazatec, a word final floating $\mathrm{L}$ is analyzed as undergoing final stray erasure when it follows a floating $\mathrm{H}$ (Williams 2004: 150). In the Chimaraba dialect of Makonde, Odden (1990: 68) explains the absence of a $\mathrm{H}$ tone in the future tense of monosyllabic stems by excluding the prefix - na-from Default Docking. Thus, the stem $\mathrm{H}$ tone remains unassociated and is subsequently deleted by stray erasure. Akumbu (2011: 8-17) also evokes stray erasure to explain the tonal patterns in the associative construction of Kejom. It will also be necessary to evoke stray erasure to explain the occasional absence of downstep in Kabiye.

\section{Overview of Kabiye}

3.1 Segments and morphology. Kabiye has 18 consonants /p, f, t, t, s, tf, k, kp , d, z, l, y, w, h, m, $\mathrm{n}, \mathrm{n}, \mathrm{y} /$ and nine vowels /i, I, u, $\mathrm{v}, \mathrm{e}, \varepsilon, \mathrm{o}, \mathrm{\rho}, \mathrm{a} /$. Vowel length is contrastive. Five long, back unrounded vowels [ư, uщ, $\gamma \gamma, \Lambda \Lambda, a \mathrm{a}$ ] occur at morpheme boundaries. In spite of some disagreement about their phonetic quality (CLNK 1999: 482; Delord 1976: 21; Lébikaza 1999: 43-44, 49-56; Padayodi 2010: 214-232), all researchers agree that they are long and tone bearing. Obstruents may be voiced in word medial position. Kabiye also has a vowel harmony system in which the features [ATR], [LABIAL] and [DORSAL] interact. Capital letters will be used to indicate underlying vowels.

Kabiye is an SVO language with ten noun classes $^{3}$ in which the verb phrase takes an optional subject pronoun prefix ${ }^{4}$ and an obligatory segmental TAM suffix. All verbs ending in a [CORONAL] consonant carry an epenthetical vowel/I/ which assimilates to that of the TAM suffix. Subject pronoun prefixes vary according to the rules of ATR vowel harmony and are all L tone except the second person plural /É-/. The latter is a tonal minimal pair with the third person singular class 1 subject pronoun /Eे-/ and this tonal contrast will be exploited to illustrate $\mathrm{H}$ and L preceding contexts.

\footnotetext{
${ }^{3}$ Noun class numbering in this paper follows Miehe \& Winkelmann (2007: 7-22).

${ }^{4}$ The subject pronoun is analyzed as being a prefix because it undergoes vowel harmony and is meaningless in isolation.
} 
The imperfective present TAM suffix / kI-/ has ten allomorphs, depending on the structure of the preceding root (Table 1). In addition, the final [LABIAL] consonant of $\mathrm{CVb}-, \mathrm{CVm}-$ and $\mathrm{CVw}$ - roots elides in certain conjugations.

Table 1: Imperfective present allomorphs

\begin{tabular}{|c|c|c|}
\hline Root structure & $-A T R$ & $+A T R$ \\
\hline CVk-, CVb- & {$[-\mathrm{kI}]$} & [-ki] \\
\hline CVm- & \multicolumn{2}{|c|}{$\left[\begin{array}{ll}1 \\
{[-1]}\end{array}\right.$} \\
\hline CEw- & {$[-\Lambda]$} & {$[-\gamma]$} \\
\hline Caw- & \multicolumn{2}{|c|}{$[-a]$} \\
\hline $\mathrm{CV}_{[\mathrm{BACK}] \mathrm{W}-}$ & {$[-\mho]$} & {$[-\mathrm{u}]$} \\
\hline elsewhere $^{5}$ & [-u] & [-ü] \\
\hline
\end{tabular}

As for the perfective /-a/ and the imperfective past [-a] TAM suffixes, they are invariable. However, in the latter case, given that back unrounded vowels only occur at morpheme boundaries, I consider the underlying form to be /-kA/, by analogy with the allomorphic patterns of the imperfective present suffix /-kI/.

\subsection{Tone}

3.2.1 Generalizations. Kabiye has two contrastive level tones, high ( $\mathrm{H},[\dot{j}])$ and low (L, [j]) (Lébikaza 1999: 184-190), although we will return to this point in Section 0 to ask whether the surface L tone may be unspecified. Both automatic and non-automatic downstep ([๖]) are attested. The TBU is the mora (Lébikaza 1999: 170, 267). All vowels are tone-bearing, as are nasals in preconsonantal position and word final position. Surface contour tones do not occur on single TBUs.

3.2.2 Postlexical HLH plateauing. A generalized post-lexical plateauing process will account for all the examples of non-automatic downstep in this paper. Any singly linked L tone between two $\mathrm{H}$ tones delinks and an adjacent $\mathrm{H}$ tone spreads on to it, with the floating (L) tone resulting in nonautomatic downstep (Lébikaza 1999: 191-195). The direction of the spread depends on the skeletal structure (Figure 1).

Figure 1: Post-lexical HLH plateauing<smiles>NC(Cl)Cl</smiles><smiles>Cl[AlH]C=[W]Cl</smiles>

\footnotetext{
${ }^{5}$ Including CIw- roots. Other possible structures are CVC-, CVCVC-, CVNC-, CVVC- and CVNCVC-.
} 
The following examples illustrate plateauing with leftward (1) and rightward (2) spreading.

$1 \quad \mathrm{CVCV}$ CV

\section{CVCVV}

CV CVN

2 CVVCV

CVNCV /nálì- $\varnothing \mathrm{kÚ} /$

wash-IMP OP3/3

/nákà-Ú/ grasshopper-CL3

/ná- $\varnothing$ tùm- $\varnothing /$

see-IMP snake-CL1

/nú-ঠ̀ dớ/
head-CL3 OWN

/téǹ-té/

LOC-SX $\rightarrow$ [nállígó] 'wash it!'

$\rightarrow$ [náłkáơ] 'grasshopper'

$\rightarrow \quad$ [ná 'dứm] $\quad$ 'see snake!'

$\rightarrow$ [nớódón] 'president'

$\rightarrow \quad$ [téń`dé] 'where'

3.2.3 Underlying tones of verb roots and their extensions. Lébikaza (1999: 195-197, 215-236) was the first to present a systematic account of the underlying forms of verb roots. He places them in two preceding substitution frames: the $\mathrm{H}$ tone adjectivizer $/ \mathrm{kI}-/$ and the $\mathrm{L}$ tone locative nominalizer /ț̇-/, thus establishing eight underlying patterns: /H, L, LL, LLL, HL, LH, LLH, LHL/ which remain stable between the two frames. Kassan (1996: 37-38, 53-54) adopts Lébikaza's underlying forms. Padayodi (2010: 279-286) uses the same frames but, by applying the OCP, reduces the list of underlying forms to five: /H, L, HL, LH, LHL/.

Roberts (2002) differs fundamentally from these previous analyses in that it considers the three tone patterns of the imperative $/ \mathrm{H}, \mathrm{L}, \mathrm{HL} /$ to be the form that reveals the lexical tone of the verb root. Since Padayodi (2010: 105-106) discusses this choice in some detail but rejects it, it should be defended. Tables 2 and 3 compare the distribution of underlying patterns according to Padayodi (2010) and Roberts (2002). The former does not systematically show mono-, di- and trimoraic roots for each posited tone pattern and it mixes noun classes, but Tables 2 and 3 fill the gaps with examples that are in harmony with that analysis. Adjectives agree with the noun they qualify (Table 2 shows class 1); Locative nominalizations are in class 5.

Table 2: Underlying patterns based on adjectives (Padayodi 2010) and imperatives (Roberts 2002)

\begin{tabular}{|c|c|c|c|c|c|c|}
\hline Moras & Padayodi & \multicolumn{2}{|l|}{ Adjectives } & Roberts & \multicolumn{2}{|c|}{ Imperatives } \\
\hline 1 & $/ \mathrm{H} /$ & 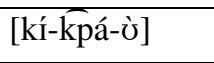 & 'climbed' & \multirow[t]{3}{*}{$/ \mathrm{H} /$} & [kpá- Ø] & 'climb!' \\
\hline 2 & \multirow[t]{2}{*}{ /LH/ } & [kí- $\downarrow_{\text {sídú-ù] }}$ & 'mixed' & & [sídí-Ø] & 'mix!' \\
\hline 3 & & [kí-wèlèsú-ù] & 'listened' & & [wélésí-Ø] & 'listen!' \\
\hline 1 & \multirow[t]{3}{*}{$/ \mathrm{L} /$} & [kí-lèmù-ú] & 'dried' & \multirow[t]{3}{*}{$/ \mathrm{L} /$} & {$[1 \mathrm{è-} \varnothing]$} & 'dry!' \\
\hline 2 & & [kí-tìzò-ó] & 'cooked' & & [tìzì- $\varnothing]$ & 'cook!' \\
\hline 3 & & [kí-sùlùmù-Ú] & 'borrowed' & & [sùlùmì- $\varnothing]$ & 'borrow!' \\
\hline 2 & /HL/ & [kú-múzù-ù] & 'sighed' & \multirow[t]{2}{*}{ /HL/ } & [múzì- $\varnothing]$ & 'sigh!' \\
\hline \multirow[t]{2}{*}{3} & /LHL/ & [kú-`hólósù-ù] & 'sipped' & & [hólósì- $\varnothing]$ & 'sip!' \\
\hline & & ADJ-RT-CL1 & & & RT-IMP & \\
\hline
\end{tabular}


Table 3: Underlying patterns based on locative nominalizations (Padayodi 2010) and imperatives (Roberts 2002)

\begin{tabular}{|c|c|c|c|c|c|c|}
\hline \multirow{2}{*}{$\begin{array}{l}\text { Moras } \\
1\end{array}$} & \multirow{2}{*}{$\begin{array}{l}\text { Padayodi } \\
(\mathbf{2 0 1 0}) \\
/ \mathrm{H} /\end{array}$} & \multicolumn{2}{|c|}{ Locative nominalizations } & \multirow{4}{*}{$\begin{array}{l}\text { Roberts } \\
\text { (2002) } \\
\text { /H/ }\end{array}$} & \multicolumn{2}{|l|}{ Imperatives } \\
\hline & & [tì-gbá-yè] & $\begin{array}{l}\text { 'climbing } \\
\text { place' }\end{array}$ & & 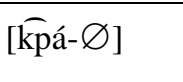 & 'climb!' \\
\hline 2 & \multirow[t]{2}{*}{ /LH/ } & [tì-zìdí-yè] & 'mixing place' & & [sídí-Ø] & 'mix!' \\
\hline 3 & & [tì-wèlèsí-yè] & $\begin{array}{l}\text { 'listening } \\
\text { place' }\end{array}$ & & [wélésí-Ø] & 'listen!' \\
\hline 1 & \multirow[t]{3}{*}{$/ \mathrm{L} /$} & [tì-lèn-dé] & 'drying place' & \multirow[t]{3}{*}{$/ \mathrm{L} /$} & [lè- Ø] & 'dry!' \\
\hline 2 & & [tì-dìzì-yć] & 'cooking place' & & [tìzì- $\varnothing]$ & 'cook!' \\
\hline 3 & & $\begin{array}{l}\text { [tì-zùlòmì- } \\
\text { yéc] }\end{array}$ & $\begin{array}{l}\text { 'borrowing } \\
\text { place' }\end{array}$ & & [sòlòmì- $\varnothing]$ & 'borrow!' \\
\hline 2 & /HL/ & [tù-múzì-yè] & 'sighing place' & \multirow[t]{2}{*}{ /HL/ } & [múzì- $\varnothing]$ & 'sigh!' \\
\hline \multirow[t]{2}{*}{3} & /LHL/ & $\begin{array}{l}\text { [tù-hòlósì- } \\
\text { yè] }\end{array}$ & 'sipping place’ & & [hólósì- $\varnothing]$ & ‘sip!’ \\
\hline & & NOM-RT-CL5 & & & RT-IMP & \\
\hline
\end{tabular}

This presentation of the data reveal that several facts about Padayodi's posited underlying patterns are suspect:

- $\quad \mathrm{H}$ (1 mora roots) and LH (2 and 3 mora roots) are in complementary distribution and neutralize in the imperative; $\mathrm{HH}$ and $\mathrm{HHH}$ are absent;

- HL (2 mora roots) and LHL (3 mora roots) are in complementary distribution and neutralize in the imperative; HHL is absent;

- The distribution of $\mathrm{H}$ (1 mora roots) and L (1, 2 and 3 mora roots) is assymetrical.

To summarize, the monomoraic H pattern, the dimoraic HL pattern and all three L patterns are uncontroversial: all researchers agree on their underlying forms. It is the addition of LH and LHL that this paper contests, because they are predictable once the presence of L tone spread from the prefix is accepted. This is what causes HH roots to surface as LH and HHL roots to surface as LHL. This is a perfectly reasonable possibility in the cases of the locative nominalization because it is preceded by a $\mathrm{L}$ tone prefix. But why would $\mathrm{L}$ tone spread occur following the adjectivizer prefix that is (apparently) H tone?

In response to this question, I posit that the tone of the adjectival prefix is not $\mathrm{H}$ but $\mathrm{HL}$ $/ \mathrm{k} \hat{\mathrm{I}}-/$. Evidence for this emerges from a closer investigation of monomoraic $\mathrm{CVw} \mathrm{H}$ roots. ${ }^{6}$ According to my informants, and contrary to the examples furnished by previous researchers, these roots (and only these) consistently reduplicate in the adjectival form and, crucially, non-automatic downstep occurs between the prefix and the $\mathrm{H}$ tone stem (Table 4).

If the adjectivizer prefix were $\mathrm{H}$, the reduplication would surface with no downstep (e.g. *[kí-kpákpá-广] 'climbed-ADJ'). Polarity of the reduplicated element, on the other hand, would explain the $\mathrm{H}$ tone roots but not the $\mathrm{L}$ tone roots. Neither of these explanations matches the data. Rather, the presence of the non-automatic downstep in the $\mathrm{CVw} \mathrm{H}$ root forms, triggered as usual by

\footnotetext{
${ }^{6} \mathrm{The} / \mathrm{w} /$ elides in both the imperative and the adjective, but is present in the perfective, as in [غ̇hàwá] 'he/she gave'. Padayodi (2010: 280-281) lists the H tone adjectives in Table 4 as [kí-kpá-wù], [kí-sé-yù], [kí-há-yù].
} 
HLH plateauing, suggests that the adjectival prefix is underlyingly /HL/ and that the L tone spreads onto the root, a process that will be dealt with further in Section 0 .

Table 4: Reduplication and non-automatic downstep in CVw adjectives

\begin{tabular}{|c|c|c|c|c|}
\hline \multirow{2}{*}{\begin{tabular}{|l|}
$\begin{array}{c}\text { Padayodi 2010, } \\
\text { Roberts 2002 }\end{array}$ \\
/H/ \\
\end{tabular}} & \multicolumn{2}{|c|}{ Imperative } & \multicolumn{2}{|l|}{ Adjective } \\
\hline & [ [kpá- $\varnothing]$ & 'climb!' & [kí-`kpákpá-ò] & 'climbed' \\
\hline & {$[$ sé- $\varnothing]$} & 'flee!' & {$[$ kí- $\downarrow$ sésé-ù] } & ‘f'led’ \\
\hline & [há- $\varnothing]$ & 'give!' & [kí-`háhá-ì] & 'given' \\
\hline \multirow[t]{4}{*}{$/ \mathrm{L} /$} & {$[$ tù- $\varnothing]$} & 'sow!' & [kú-dùdù-ú] & 'sown' \\
\hline & {$[\mathrm{h} \grave{\varepsilon}-\varnothing]$} & 'cool!' & [kí-hغ̀h̀̀-Ú] & 'cooled' \\
\hline & {$[$ lì- $\varnothing]$} & 'soak!' & [kí-lìlì-ú] & 'soaked' \\
\hline & RT-IMP & & ADJ-ST-CL3 & \\
\hline
\end{tabular}

It is also helpful to compare verb phrases with associative noun phrases, because the two environments are analogous with respect to $L$ tone spread. A L possessive pronoun prefix spreads across the noun in the same way as a L negative prefix spreads across imperative (Table 5). ${ }^{7}$

Table 5: Parallel $L$ tone spread in nouns and verbs

\begin{tabular}{|c|c|c|c|c|c|}
\hline & Imperative & & & Prohibitive & \\
\hline $\mathrm{HH}$ & [kádí- $\varnothing]$ & 'lock!' & L-LH & [tàà-kàdí-Ø] & 'don’t lock!' \\
\hline $\mathrm{HHH}$ & [wélésí- $\varnothing$ ] & ‘listen’! & L-LLH & [tàà-wèlèsí- $\varnothing]$ & 'don’t listen!' \\
\hline \multirow[t]{4}{*}{ HHL } & [tákáyì- $\varnothing$ ] & 'limp!' & L-LHL & [tàà-tàkáyì- Ø] & 'don't limp!' \\
\hline & RT-IMP & & & NEG-RT-IMP & \\
\hline & & & & & \\
\hline & Noun & & & PP+Noun & \\
\hline $\mathrm{HH}$ & [wól-ú] & 'sister-in-law' & L-LH & [è-wòl-ú] & 'his/her sister-in-law' \\
\hline $\mathrm{HHH}$ & [tádÍ-yé] & 'commerce' & L-LLH & [غ̀-tàdì-yć] & 'his/her commerce' \\
\hline \multirow[t]{2}{*}{ HHL } & [nómó-ঠ̀] & 'journey' & L-LHL & [غ่-nว̀mó-ঠ̀] & 'his/her journey' \\
\hline & RT-SX & & & PP3/1-RT-SX & \\
\hline
\end{tabular}

If the underlying forms of these verb roots were /LH, LHL/ as previous authors have claimed, then logically the same should apply to nouns. Then isolated nouns would not reveal their underlying forms, and nouns, like verbs, would be unaccountably bereft of $(\mathrm{H}) \mathrm{HH}$ and $\mathrm{HHL}$ patterns. As it is, previous researchers give nouns and verbs entirely independent treatment.

If an analysis based on the three imperative tone patterns can adequately explain the five patterns of the adjectival and nominalized forms, the reverse must be tested too: How does an analysis based on the five adjectival and nominalized forms account for the three imperative patterns? Unfortunately, Padayodi's analysis is silent on this subject, as it is concerning all the major verb inflections. As for Lébikaza (1999: 351), he claims that the H tone of a LH root spreads

\footnotetext{
${ }^{7}$ Comparing monomorphemic imperatives with dimorphemic nouns is valid because noun root tone patterns associate to entire words (Roberts 2016). Monomorphemic nouns share the same patterns but would be less convincing because they tend to be borrowed words.
} 
leftwards onto the preceding mora in the imperative. Of the two contested /LH, LHL/ patterns, he only touches on LH, and lists only one data item. It is therefore difficult to evaluate this hypothesis with any clarity.

In summary, Padayodi's and Lébikaza's accounts of verb tone, for all their insightfulness on certain issues, do not succeed in identifying the underlying tone patterns. At the most basic level, any analysis that can successfully account for all the data with three underlying patterns is more economical than one that needs five or eight patterns, especially if it can provide an integrated account of nouns and verbs. But more importantly, neither of the previous researchers offer a credible account of how imperatives are formed, and they both overlook the complementary distribution of their own posited underlying tone patterns.

For these reasons, it seems preferable to follow Roberts (2002) in considering the imperative as being the form that is closest to the underlying form of the verb root. However, recent research reveals that this analysis too is insufficient because, although it makes an early passing reference to simple and complex stems (p. 4), it fails to analyze them separately and therefore misses crucial insights (Snider 2018: 34-35). Table 6 provides some examples.

Table 6: Verbal extensions

\begin{tabular}{|l|l|l|l|l|l|}
\hline Suffix & Value & Root & & Root+extension & \\
\hline /-sI-/ & causative & {$[$ tgàà- $\varnothing]$} & 'sit!' & [tgáá-zì- $\varnothing]$ & 'cause to sit!' \\
\hline /-yI-/ & intensive & {$[$ màà- $\varnothing]$} & 'jump!' & [má-yí- $\varnothing]$ & 'jump for joy!' \\
\hline /-tI-/ & diminutive & {$[$ ṫ̀̀- $\varnothing]$} & 'finish!' & [t'́-dì- $\varnothing]$ & 'become rare!' \\
\hline & & RT-IMP & & RT-EXT-IMP & \\
\hline
\end{tabular}

Only $20 \%$ of verbs in my corpus are identifiable as having morphologically complex stems, but this does not mean that others are not: they may involve cranberry morphemes that cannot (or can no longer) be assigned an independent meaning. Five considerations weigh in favor of this hypothesis: (i) The tone patterns of suspect stems exactly match those with identifiable stems; (ii) stems with a $\mathrm{C}_{4}$ that duplicates a $\mathrm{C}_{3}$, or a $\mathrm{C}_{3}$ that duplicates a $\mathrm{C}_{2}$ (e.g. *[welesi-si] 'cause to listen', derived from [welesi] 'listen') are never attested; (iii) the HL pattern is absent in the unextended roots; (iv) the $\mathrm{V}_{2}$ of trimoraic forms is a copy of the $\mathrm{V}_{1}$; and (v) the meanings are often complex. For a more detailed explanation of these arguments, see Roberts (2019). Roots previously analyzed as dimoraic and trimoraic are therefore now reanalyzed as being monomoraic with one and two extensions respectively, and therefore forming stems (Table 7).

Table 7: Previous and current analyses of imperative surface tone patterns

\begin{tabular}{|l|l|l|l|l|}
\hline Moras & $\begin{array}{l}\text { Roberts } \\
\mathbf{( 2 0 0 2})\end{array}$ & $\begin{array}{l}\text { Surface } \\
\text { patterns }\end{array}$ & Roberts (this paper) & Surface patterns \\
\hline 1 & root & H, L & root & H, L \\
\hline 2 & root & HH, LL, HL & $\begin{array}{l}\text { stem (root + 1 } \\
\text { extension) }\end{array}$ & H-H, L-L, H-L \\
\hline 3 & root & $\begin{array}{l}\text { HHH, LLL, } \\
\text { HHL }\end{array}$ & $\begin{array}{l}\text { stem (root + } \\
\text { extensions) }\end{array}$ & $\begin{array}{l}\text { H-H-H, L-L-L, H- } \\
\text { H-L }\end{array}$ \\
\hline
\end{tabular}

But even this reanalysis falls one step short of revealing the underlying forms. The next section demonstrates why adjacency concerns require positing underspecification of the L extension 
in $(\mathrm{H})-\mathrm{H}-\mathrm{L}$ stems, so that the underlying forms of the unextended roots are $/ \mathrm{H}, \mathrm{L} /$ and those of the extensions reveal a ternary /-H, $-\mathrm{L},-\varnothing /$ contrast.

3.2.4 Polarity and underspecification. We begin by observing that all derivational noun class suffixes, whether adjectives (3) or locative nominalizations (4), surface as L if the stem (i.e. root + extension) contains an $\mathrm{H}$, and as $\mathrm{H}$ otherwise.

\begin{tabular}{|c|c|c|c|c|c|}
\hline$/ \mathrm{H} /$ & {$\left[\mathrm{kí}^{\prime}\right.$} & $\mathfrak{y} \grave{\varepsilon}$ & $-l u ́$ & $-\grave{\circlearrowright}]$ & 'given back' (ADJ) \\
\hline /L/ & [kí- & hà & $-z \grave{~}$ & $-u ́]$ & 'swept' (ADJ) \\
\hline /HL/ & {$\left[\mathrm{kI}^{\prime}-\right.$} & $\mathrm{k} \varepsilon^{\prime}$ & 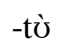 & $-\dot{u}]$ & 'shelled' (ADJ) \\
\hline & ADJ & RT & EXT & CL3 & \\
\hline$/ \mathrm{H} /$ & {$[\mathrm{tì}-$} & $\mathfrak{f} \grave{\varepsilon}$ & -lí & $-y \grave{\varepsilon}]$ & 'place of giving back' \\
\hline /L/ & [tì- & hà & -zì & 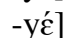 & 'place of sweeping' \\
\hline /HL/ & {$[\mathrm{tì-}$} & $\mathrm{k} \varepsilon^{\prime}$ & -tì & $-y \grave{c}]$ & 'place of shelling' \\
\hline & LOC & RT & EXT & CL6 & \\
\hline
\end{tabular}

This tonal pattern is exactly matched in inflectional TAM suffixes, whether imperfect present (5), imperfective past (6) or perfective (7).

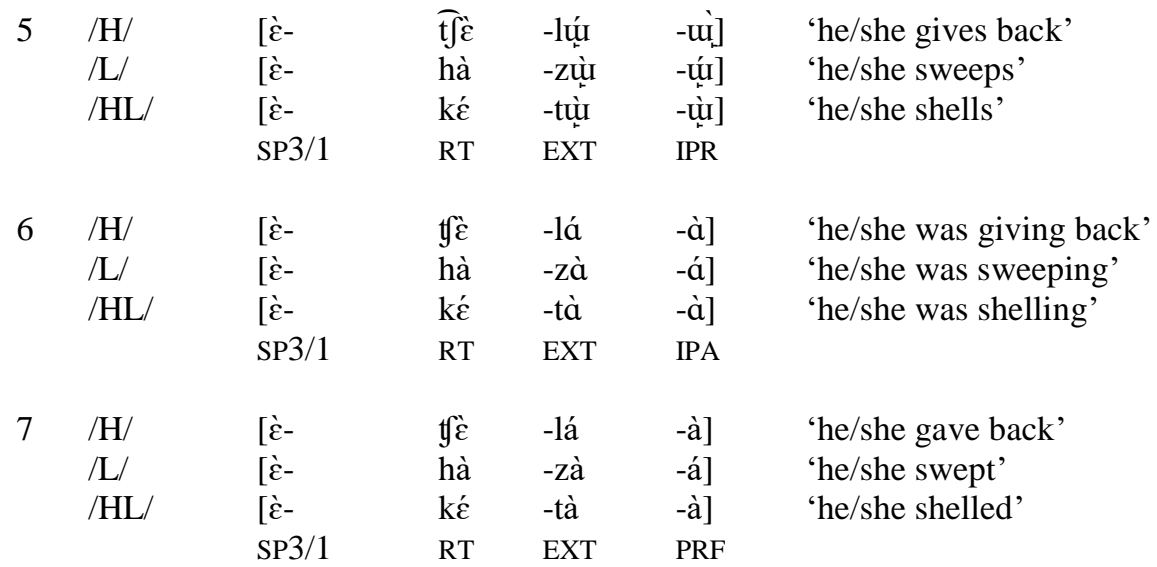

It therefore looks likely that all these derivational and inflectional suffixes are undergoing some kind of polarity or dissimilation process. However, either possibility requires an explanation of why two adjacent $\mathrm{L}$ tones flank the morpheme boundary between the HL stem and the TAM suffix, since one of the widely agreed stipulations of autosegmental phonology is that only adjacent tones influence each other (Odden 1994). So could $\mathrm{L}$ tone underspecification account for the $\mathrm{L}$ tone TAM suffix following a HL stem, thereby causing the stem tone and the TAM suffix to be adjacent on the tonal tier? And if underspecification is necessary, how extensive is it?

The broadest option would be to analyze the whole tone system as privative. However, as already noted (Section 2.2) such analyses are best suited to languages displaying a certain asymmetry between the two surface tones. Kabiye exhibits no such thing: nouns in particular exploit the full range of potential tone patterns in a highly symmetrical fashion (Roberts 2016). Privative underspecification is also appropriate in languages where the surface $\mathrm{L}$ tone is phonologically inert. But in Kabiye $L$ tone spread from the prefix suggests that $L$ tone is an active force. If it were underspecified, it would be difficult to account for why the left-hand branch of a $\mathrm{H}$ tone in the verb 
stem delinks before "nothing”. Similarly, HLH plateauing is triggered by the presence of a L tone, not, as in Akaselem (Roberts 2017), as an OCP repair strategy to avoid the adjacency of two H tones across a morpheme boundary, as illustrated by the following Kabiye examples contrasting the habitual and adversative modal prefixes which are tonally minimal (8):

\begin{tabular}{|c|c|c|c|c|c|c|c|}
\hline $\begin{array}{l}/ \mathrm{E}- \\
\mathrm{SP} 3 / 1\end{array}$ & $\begin{array}{l}\text { tIIÍ- } \\
\text { HAB }\end{array}$ & $\begin{array}{l}\text { háw } \\
\text { RT }\end{array}$ & & $\begin{array}{l}-\mathrm{kI} / \\
\mathrm{IPR}\end{array}$ & $\rightarrow$ & [غ̀-tíí-há-à] & 'he/she usually gives' \\
\hline $\begin{array}{l}/ \mathrm{E}- \\
\mathrm{SP} 3 / 1\end{array}$ & $\begin{array}{l}\text { tî̀- } \\
\text { ADV }\end{array}$ & $\begin{array}{l}\text { háw } \\
\text { RT }\end{array}$ & & $\begin{array}{l}-\mathrm{kI} / \\
\mathrm{IPR}\end{array}$ & $\rightarrow$ & [غ̀-tíl- ${ }^{\downarrow}$ há-à] & 'he/she gives in spite of it' \\
\hline $\begin{array}{l}\text { /È- } \\
\text { SP3/1 }\end{array}$ & $\begin{array}{l}\text { tÎÍ- } \\
\text { HAB }\end{array}$ & $\begin{array}{l}\text { ká } \\
\text { RT }\end{array}$ & $\begin{array}{l}\text { tì } \\
\text { EXT }\end{array}$ & $\begin{array}{l}\text {-kI/ } \\
\text { IPR }\end{array}$ & $\rightarrow$ & [غ̀-tíi-kátù-ù̀] & 'he/she usually meets' \\
\hline $\begin{array}{l}\text { /È- } \\
\text { SP3/1 }\end{array}$ & $\begin{array}{l}\text { tÎ̀- } \\
\text { ADV }\end{array}$ & $\begin{array}{l}\text { ká } \\
\text { RT }\end{array}$ & $\begin{array}{l}\text { tì } \\
\text { EXT }\end{array}$ & $\begin{array}{l}-\mathrm{kI} / \\
\mathrm{IPR}\end{array}$ & $\rightarrow$ & [غ̀-tíl'-`kátù̀-ù̀] & 'he/she meets in spite of it' \\
\hline
\end{tabular}

As we will see in Section 0 the concatenation of the imperfective past will require the presence of a floating L tone TAM prefix, which is additional evidence in support of it being phonologically active. Finally, a privative account would have difficulty explaining why entire phonological phrases occasionally surface with only L tones (9). ${ }^{8}$

\begin{tabular}{|c|c|c|c|}
\hline $\begin{array}{l}\text { [wòlò- } \varnothing \\
\text { go-IMP }\end{array}$ & $\begin{array}{l}\text { màzà-à } \\
\text { Saturday- CL12 }\end{array}$ & $\begin{array}{l}\text { kìyàk-ঠ̀ } \\
\text { market- CL3 }\end{array}$ & $\begin{array}{l}\text { kpààgbàà] } \\
\text { directly }\end{array}$ \\
\hline \multicolumn{4}{|c|}{ 'Go directly to the Saturday market!' } \\
\hline$[\grave{\varepsilon}$-fòlı̀t’̀- $\varnothing$ & mààmàà & wè- $\varnothing$ & hùnjàmm̀̀] \\
\hline PP3s/1-bag-CL3 & itself & be-PRF & light \\
\hline
\end{tabular}

For all the reasons, a privative approach is not convincing. A more convincing explanation involves a local ternary $/ \mathrm{H}, \mathrm{L}, \varnothing /$ contrast on the verbal extensions, with a default $\mathrm{L}$ tone being assigned to the toneless TBU in the postlexical stage. This will be the approach taken in the following analysis.

As for whether the derivational and inflectional suffix tones display dissimilation or polarity, the latter is preferable for the following reason. A previous account of the noun system showed that singular noun class suffixes are underlyingly toneless (Roberts 2016), and since these same morphemes mark the adjectival and nominalized forms, these must undergo polarity, because dissimilation would require an underlying tone. As for the inflectional suffixes, there is no a priori reason why they should be considered toneless just because they occupy the same slot as derivational suffixes but given that the word level tone patterns match exactly, polarity enables a single integrated analysis for both (Figure 2).

\footnotetext{
${ }^{8}$ Admittedly, this would not be convincing unilateral evidence for underspecification since some languages have toneless roots.
} 
Figure 2: Derivational and inflectional suffix polarity

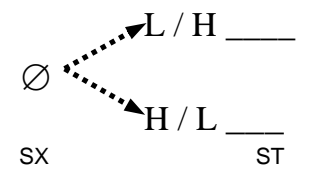

Figure 3 shows the derivation of the imperfective present of di- and trimoraic $/(\mathrm{H})-\mathrm{H}-\varnothing /$ stems, illustrating how, because the extension is toneless, the TAM suffix tone is adjacent to that of the root on the tonal tier.

Figure 3: TAM suffix polarity in the imperfective present forms of di- and trimoraic $/(\mathbf{H})$ H- $\varnothing /$ stems

$/ \mathrm{H}-\varnothing /$

Root

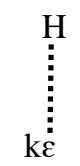

RT

Add extension(s)

Add TAM suffix

Polarity
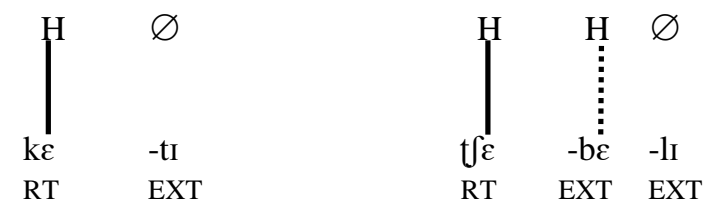

Default L insertion

Surface form

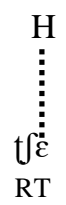

$\mathrm{RT}$
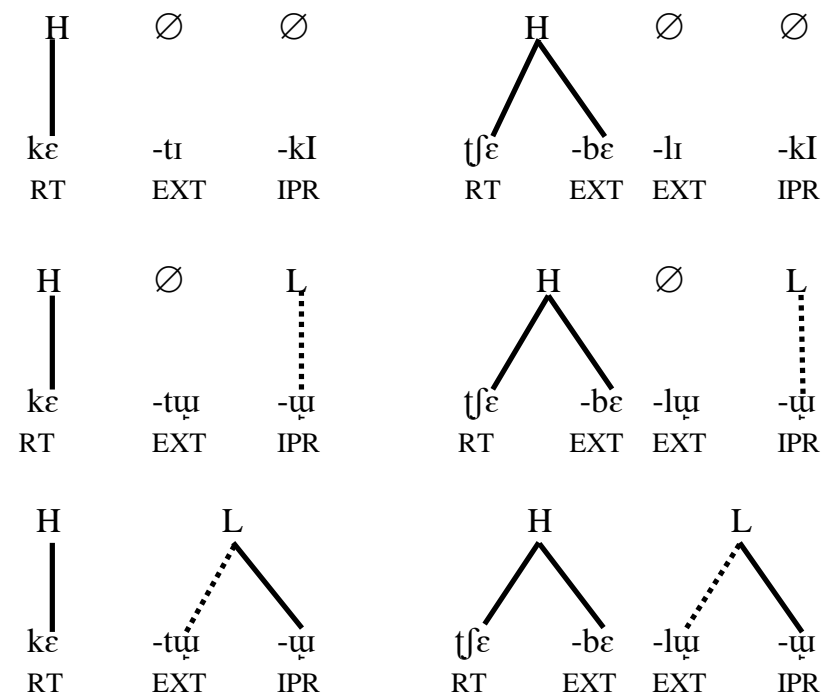

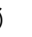 \\ I} IPR

[kétù̀ùu] 'shell'-IPR

3.2.5 Lexical $\mathbf{L}$ tone spread. Section 0 has already demonstrated that $\mathrm{L}$ tone spread explains the tone patterns of adjectival and locative derivations; we now return to that phenomenon to define it and describe it in detail. The source of $L$ tone spread in the verb phrase is any $L$ tone prefix and its target is the stem. The $\mathrm{L}$ tone of the prefix spreads right onto the stem until it is blocked by a singly 
linked $\mathrm{H}$, that is, across a maximum of two moras. Thus spreading eliminates association lines, not tones (Figure 4).

Figure 4: Lexical $L$ tone spread

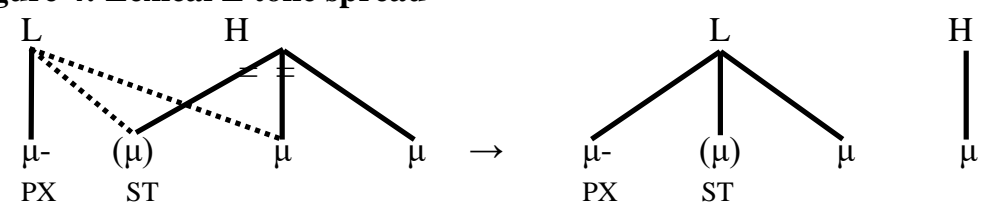

Figure 5 illustrates the application of this rule in the prohibitive verb phrase.

Figure 5: Lexical $L$ tone spread in the prohibitive verb phrase

Root

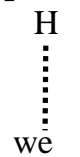

Add extensions

wè

RT

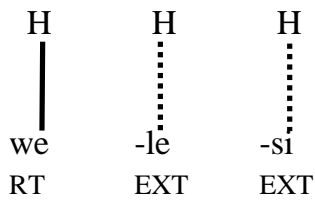

Add prohibitive prefix

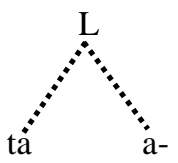

NEG

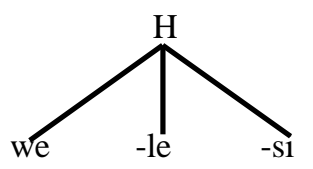

RT EXT EXT

L tone spread

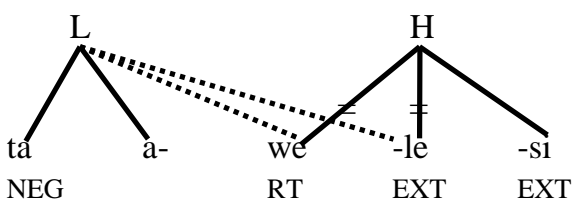

Surface form

[tààwèlèsí] 'Don’t listen!'

Example 10 illustrates this process with other L tone prefixes, with the moras affected by $\mathrm{L}$ tone spread highlighted in grayscale. ${ }^{9}$ It should be emphasized that L tone spread is not a generalized process in Kabiye; it only occurs in the distinctive morphological context of a $\mathrm{L}$ tone prefix before a stem, and only within phonological words. It cannot be described without reference to the morphology and is therefore a lexical process.

\footnotetext{
${ }^{9}$ As for $\mathrm{L}$ tone stems, the first TBU carries a $\mathrm{H}$ tone when preceded by a L prefix, e.g. [tàà-lú-lù-sì- $\varnothing$ ] 'don't decant!' [è-tò-lú-lù-sì- $\varnothing]$ 'he/she did not decant'. I currently have no explanation for this.
} 


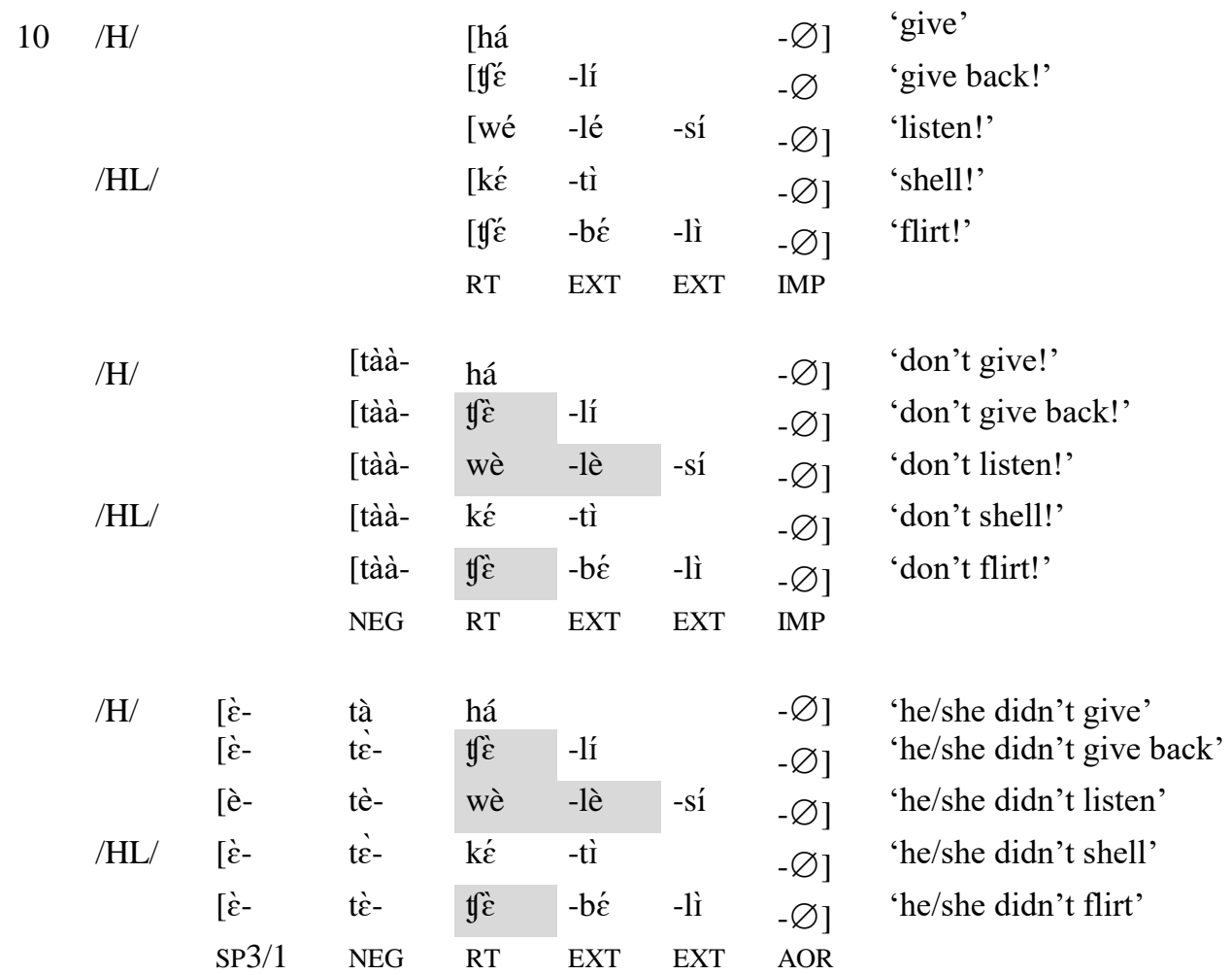

3.2.6 Stray erasure. Stray erasure stipulates that, when a floating L tone has done all the spreading and merging it can do and is left unassociated at the end of the lexical derivation, it is erased completely following the lexical output and before plateauing (Figure 6).

\section{Figure 6: Floating $L$ tone stray erasure}

(L) $\rightarrow \varnothing$

Condition: between lexical output and plateauing

This rule accounts for the lack of non-automatic downstep in example (11), combining a $\mathrm{H}$ (L) prefix with a HL stem, that was already encountered in Table 2.

$11 /$ k̂̂- mú zì $\quad-\mathrm{U} / \quad \rightarrow \quad$ [kúmúzùù] not *[kú ${ }^{\downarrow}$ múzùù] 'sighed' (adj.) ADJ RT EXT CL1

Stray erasure will also be evoked in the presentation of the imperfective past (Sections 4.3.2) and some irregular forms (Section 0).

\section{Tonology of the verb phrase}

4.1 Lexical phonology model. Having defined the major tonal processes, we are now in a position to develop an integrated Lexical Phonology model that will account for all derivational and inflectional forms (Figure 7). 
Figure 7: Lexical phonology model of derivational and inflectional forms

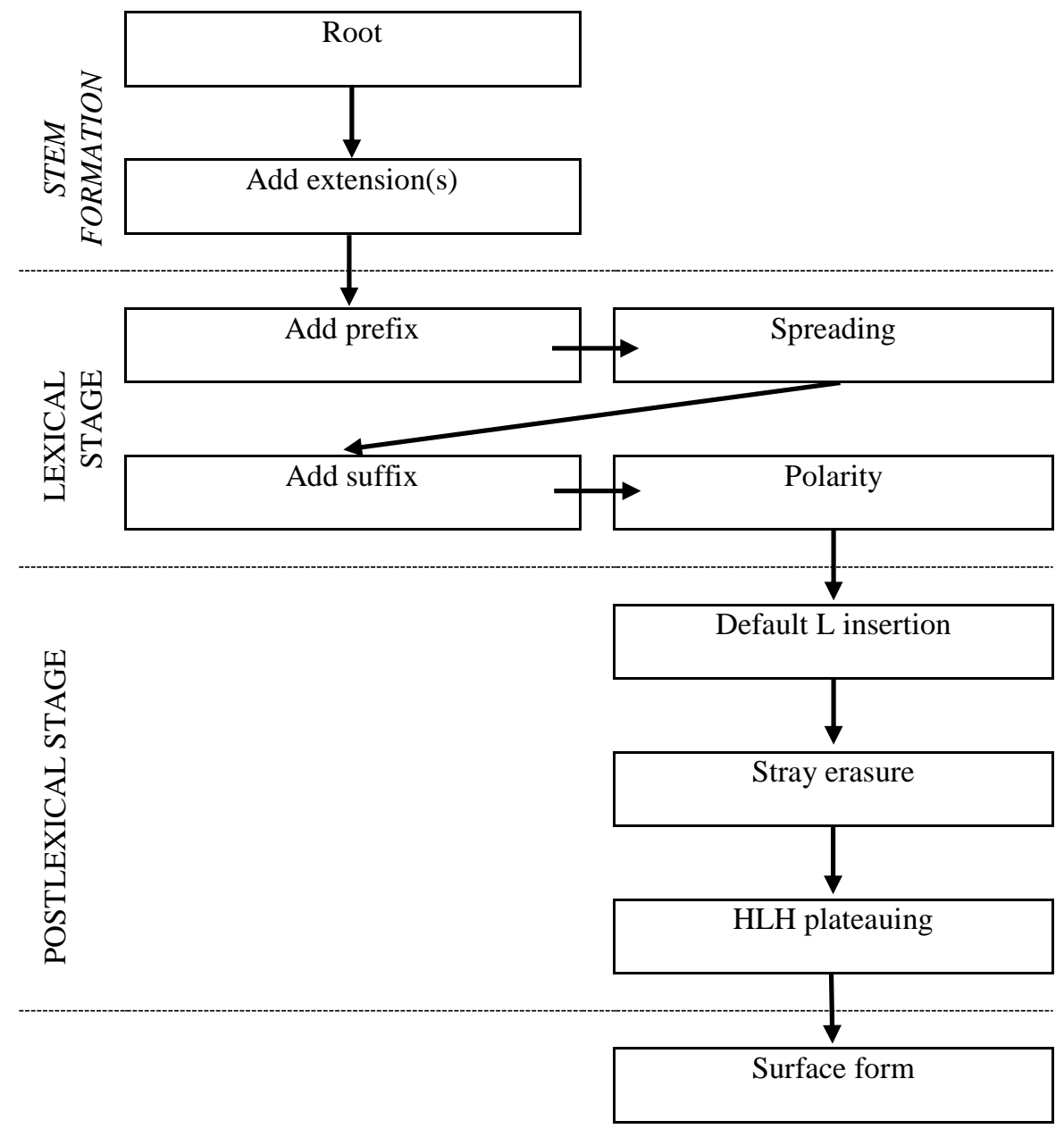

Figure 7 shows that, after the initial root tone association, a maximum of two verbal extensions may be added to form the stem. In the second, lexical stage, the TAM prefix is added and spreads on to the stem, then the toneless TAM suffix is added and receives its tone by polarity. The lexical cycle is repeated if a subject pronoun is added. It might seem tempting to eliminate a stage in the derivation by analyzing the TAM prefix and suffix as a circumfix. However, rule ordering weighs against this option because spreading (associated with the prefix) must take place before polarity (associated with the suffix) for reasons that will be explained in Section $0 .{ }^{10}$ In the postlexical stage, any toneless TBUs receive their tone by default $\mathrm{L}$ insertion and any remaining floating tones are deleted by stray erasure. These two processes are considered to be postlexical because they can be described without reference to the morphology. Finally, HLH plateauing occurs if the conditions are met before surfacing. All the Figures in the following sections apply this model strictly, but in each case only relevant stages are listed. We begin with adjectives (Section 0 ) and locative nominalizations (Section 0 ).

${ }^{10} \mathrm{cf}$. Creissels (2021): "Circumfixes [...] are sometimes mentioned in descriptions of Niger-Congo languages, but in most cases [...] a closer look at the data leads to the conclusion that they are best analyzed as the combination of two distinct morphemes." 


\subsection{Derivational forms}

4.2.1 Adjectives. Class 1 adjectives with trimoraic $/ \mathrm{H}-\mathrm{H}-\varnothing /$ stems illustrate $\mathrm{L}$ tone spread, polarity, and default $\mathrm{L}$ insertion (Figure 8). The $\mathrm{L}$ tone of the /HL/ adjectival prefix spreads onto the stem, delinking from the prefix to avoid a surface contour tone on a single TBU. The TAM suffix surfaces as $\mathrm{L}$ because the extension is toneless, and it is therefore adjacent on the tonal tier to the previous $\mathrm{H}$ tone.

Figure 8: Derivation of class 1 adjectives with trimoraic $/ \mathrm{H}-\mathrm{H}-\varnothing /$ stems

\section{STEM FORMATION}

Root

$$
\begin{gathered}
\mathrm{H} \\
\vdots \\
\vdots \\
\text { ho }
\end{gathered}
$$

RT

Add extension(s)

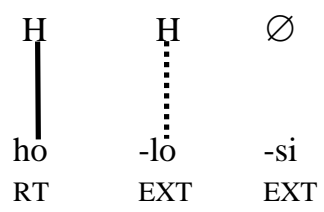

\section{LEXICAL STAGE}

Add adjectival prefix
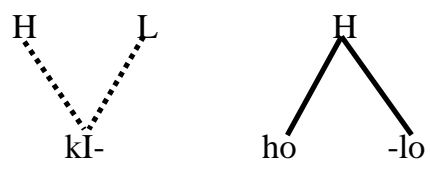

$\varnothing$

ADJ

RT EXT EXT

Spreading

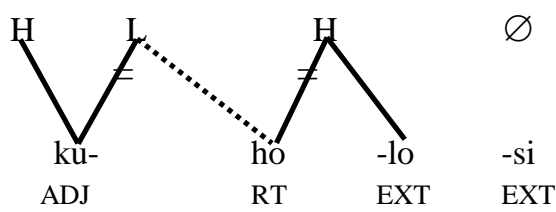

Add adjectival suffix

Polarity

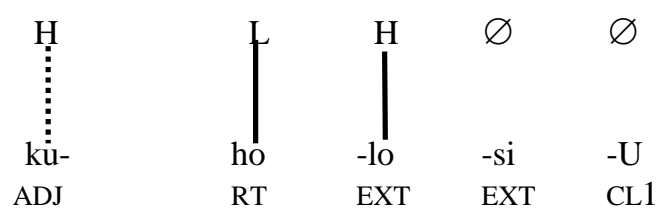

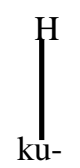

ADJ
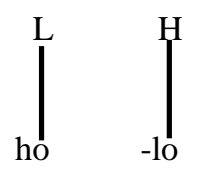

$\varnothing$

RT

EXT $\varnothing$

Si

EXT

EXT CL1

-su -u

EXT CL1 
POSTLEXICAL STAGE

Default L insertion

Plateauing

Surface form $\left.\right|_{\mathrm{ku}-} ^{\mathrm{H}}$

ADJ

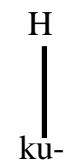

ADJ $\left.\right|_{\text {ho }} ^{\text {L }}$

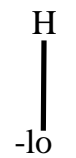

RT

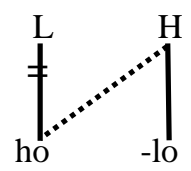

RT EXT

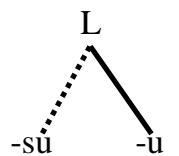

EXT CL1

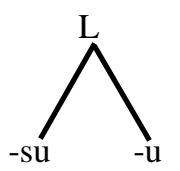

EXT CL1

Until this point, all adjectives cited have been from class 1, but Table 8 shows that all singular classes have identical tone patterns. The $\mathrm{L}$ of the HL prefix spreads right onto the first mora of any HH, HHH or HHL stem, and if this process results in HLH as the output of the lexical phonology, it triggers non-automatic downstep post-lexically at the prefix-stem morpheme boundary. The $\mathrm{L}$ of the HL prefix simply merges with any stem that is $\mathrm{L}$.

Table 8: Tone patterns on singular adjectives

\begin{tabular}{|c|c|c|c|c|c|}
\hline Stem tone & Moras & Classes 1, 3 & Class 5 & Class 12 & \\
\hline \multirow[t]{3}{*}{$/ \mathrm{H} /$} & 1 & [kí-`kpá-kpá-ঠ̀] & [kí-`'kpá-kpá-yغ̀] & [kí-`'kpá-kpá-à] & 'climbed' \\
\hline & 2 & [kí- ${ }^{\downarrow}$ sídú-ù] & [kí-`sídí-yè] & [kí-``sídá-à] & 'mixed' \\
\hline & 3 & [kí-wèlèsú-ù] & [kí-wèlèsí-yè] & [kí-wèlèsá-à] & 'listened' \\
\hline \multirow[t]{3}{*}{$/ \mathrm{L} /$} & 1 & [kí-lèmù-ú] & [kí-lèmì-yé] & [kí-lèmà-á] & 'dried' \\
\hline & 2 & [kí-tìzù-Ú] & [kí-tìzì-ý́c] & [kí-tìzà-á] & 'cooked' \\
\hline & 3 & [kú-sòlùmù-ú] & [kú-sùlùmì-yć] & [kú-sùlùmà-á] & 'borrowed' \\
\hline \multirow{3}{*}{$/ \mathrm{H}-\varnothing /$} & 2 & [kú-múzù-ù] & [kú-múzì-yè] & [kú-múzà-à] & 'sighed' \\
\hline & 3 & [kú-`hólósù-ù] & [kú-`hólósì-yè] & [kú-`hólósà-à] & 'sipped' \\
\hline & & ADJ-ST-CL1, 3 & ADJ-ST-CL5 & ADJ-ST-CL12 & \\
\hline
\end{tabular}

4.2.2 Locative nominalizations. Locative nominalizations follow a similar pattern to adjectives, but the source of $\mathrm{L}$ tone spread is more obvious because the prefix has a $\mathrm{L}$ tone. Again, the TAM suffix surfaces as L because the extension is toneless, and is therefore adjacent on the tonal tier to the root $\mathrm{H}$ tone. The extension receives its $\mathrm{L}$ tone by default later in the derivation. 
Figure 9: Locative nominalization derivation of trimoraic $/ \mathrm{H}-\mathrm{H}-\varnothing /$ stems STEM FORMATION

Root

$$
\begin{array}{r}
\mathrm{H} \\
\vdots \\
\vdots \\
\text { ho }
\end{array}
$$

RT

Add extension(s)

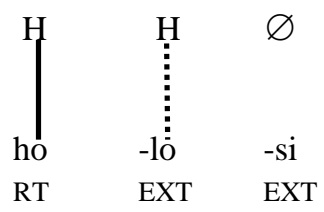

\section{LEXICAL STAGE}

Add nominalizing prefix

$$
\text { L }
$$

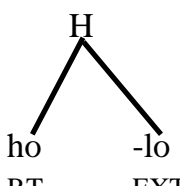

$\varnothing$

$$
\text { LOC/CL5 }
$$

RT EXT

- si

EXT

Spreading

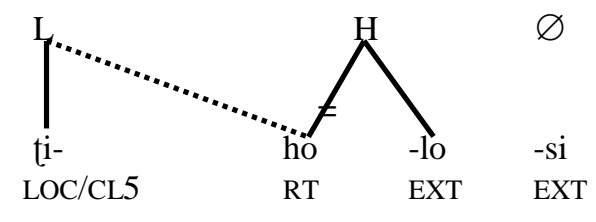

Add nominalizing suffix

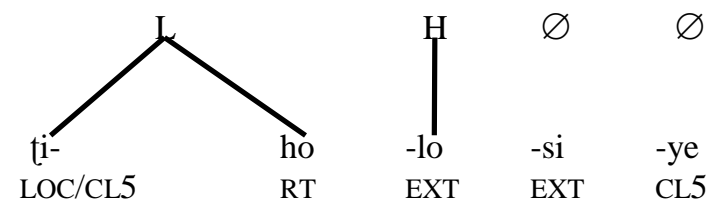

Polarity

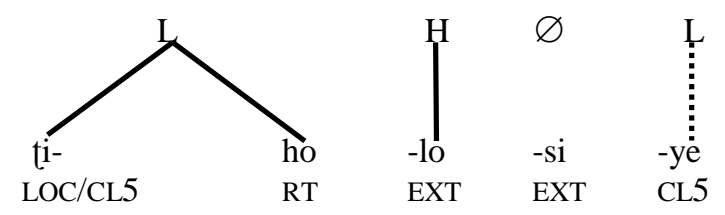

POSTLEXICAL STAGE

Default L insertion
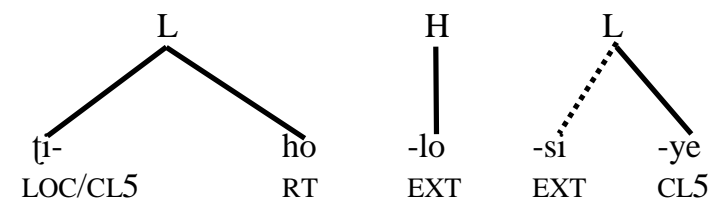

Surface form

[tìhòlósìyè] 'sipping place' 
4.3 Inflected forms. Now we move on to the three major inflected forms: the imperfective present (Section 0), the imperfective past (Section 0), the perfective (Section 0) and two types of irregularity (Section 0). The analysis will demonstrate that a simple verb phrase that appears to be composed of only a subject pronoun, a root (or stem) and a TAM suffix actually hides a floating tonal TAM prefix (Figure 10).

\section{Figure 10: Morphological structure of the simple verb phrase}

\begin{tabular}{|c|c|}
\hline $\begin{array}{c}\text { Subject } \\
\text { pronoun })\end{array}$ & $+\begin{array}{c}\text { Floating tone } \\
\text { TAM prefix }\end{array}$
\end{tabular}$+$ Root + Extension(s) $+\begin{gathered}\text { Segmental } \\
\text { TAM suffix }\end{gathered}$

The analysis will establish a second ternary contrast in the TAM prefix slot: / $\mathbb{A}-$-/ (imperfective present), /(L)-/ (imperfective past) and / $\varnothing-/$ (perfective).

4.3.1 Imperfective present. The imperfective present is framed by a floating / $(\mathbb{H}-/$ tone TAM prefix and a toneless segmental TAM suffix /-kI/ ${ }^{11}(12)$.

\begin{tabular}{|c|c|c|c|c|c|c|c|c|}
\hline \multirow[t]{2}{*}{$12 / \mathrm{H} /{ }^{12}$} & /È- & \multicolumn{3}{|l|}{ (H)- háw } & \multicolumn{2}{|l|}{$-\mathrm{kI} / \rightarrow[\grave{\varepsilon}-$ há } & \multirow{2}{*}{$-\grave{a}]$} & 'he/she gives' \\
\hline & /È- & (H)- lúw & & & -kI/ $\rightarrow$ [è- lú & & & 'he/she draws (water)' \\
\hline /L-L/ & /È- & (H)- Tfầ & & & $-\mathrm{kI} / \rightarrow\left[\grave{\varepsilon}-\widetilde{\mathrm{t}} \mathrm{Cá}^{\prime}\right.$ & & $-\mathrm{kì}]^{13}$ & 'he/she sits down' \\
\hline & /È- & $\mathbb{H}$ - hà & -Zì & & $-\mathrm{kI} / \rightarrow[\grave{\varepsilon}-$ há & -zù̀ & -ù̀] & 'he/she sweeps' \\
\hline & /È- & $\mathbb{H}$ - kè & -lè & -sì & -kI/ $\rightarrow$ [è- ké & -lé -sù & $-\mathrm{ù}]^{14}$ & 'he/she rinses' \\
\hline$/ \mathrm{H}-\varnothing$ & /È- & 1)- ḱ & -tI & & $-\mathrm{kI} / \rightarrow[\grave{\varepsilon}-\mathrm{k} \dot{\varepsilon}$ & -tù̀ & -ù̀] & 'he/she shells' \\
\hline & /È- & (H)- pú & $-z i$ & & $-\mathrm{kI} / \rightarrow[\mathrm{è-}$ pú & -zù & $-\mathrm{u}]$ & 'he/she suspends' \\
\hline & /È- & (H)- kpé & $-\mathrm{ki}$ & & $-\mathrm{kI} / \rightarrow\left[\mathrm{è}^{-} \widehat{\mathrm{kp}} \dot{r}\right.$ & $-\grave{\gamma}$ & -ù $]^{15}$ & 'he/she pardons' \\
\hline & /È- & (H)- tg' & -bé & $-\mathrm{lI}_{\mathrm{I}}$ & $-\mathrm{kI} / \rightarrow\left[\grave{\varepsilon}^{-} \mathfrak{t}^{\prime} \varepsilon\right.$ & -bé -lù & [-ழ̀] & 'he/she flirts' \\
\hline & $\begin{array}{l}\text { /È- } \\
\mathrm{SP} 32\end{array}$ & $\begin{array}{l}\text { (H)- tú } \\
\text { IPR RT }\end{array}$ & $\begin{array}{l}\text {-lú } \\
\text { EXT }\end{array}$ & $\begin{array}{l}-\mathrm{si} \\
\text { EXT }\end{array}$ & $\begin{array}{l}-\mathrm{kI} / \rightarrow \text { [è- tú } \\
\mathrm{IPR}\end{array}$ & -lú -sù & -ù] & 'he/she demolishes' \\
\hline
\end{tabular}

The floating / $(\mathbb{H}-/$ tone spreads rightwards, merging with /H/ and /HL/ stems, and delinking the $\mathrm{L}$ tone of $/ \mathrm{L} /$ tone stems. In di- and trimoraic stems, it does not attain the final mora. A reviewer has suggested that $\mathrm{H}$ tone spread may mirror $\mathrm{L}$ tone spread, continuing until it is blocked by a singly linked $\mathrm{L}$ tone. However, if that were the case, the floating $/ \mathbb{H}-/$ tone TAM prefix would not spread onto the singly linked L tone of monomoraic stems such as /È- $\mathbb{H}-1$ tàk-kI/ $\rightarrow$ [غ̀-tyá-kì] 'he/she sits down'.

\footnotetext{
${ }^{11}$ The ten allomorphs of the imperfective present TAM suffix are listed in Table $\mathbf{1}$.

${ }^{12} \mathrm{Di}$ - and trimoraic $\mathrm{H}$ tone stems are treated separately because they are irregular (see Section 4.3.4).

${ }^{13}$ When a L tone /CVk-/ stem takes the imperfective present suffix /-kI/, the underlying gemination is realized as [k] as in this example; my corpus contains 21 examples.

${ }^{14}$ According to the allomorphic patterns of the imperfective present TAM suffix (Table 1, Section 0), this form should surface as *[è-kélésừ-ụ̀]. I have no explanation for why it does not, but the tone pattern is regular.

${ }^{15}$ When a HL tone $/ \mathrm{CV}_{\text {[front] }} \mathrm{k}-/$ stem takes the imperfective present suffix /-kI/, the underlying gemination is realized as a long back unrounded vowel; my corpus contains 2 examples. When a $\mathrm{HL}$ tone / $\mathrm{CV}_{\text {[back] }} \mathrm{k}-/$ stem takes the imperfective present suffix /-kI/, the underlying gemination is realized as [k]; my corpus contains 52 examples.
} 
Figure 11 shows the concatenation of trimoraic/L/ tone stems to illustrate polarity and $\mathrm{H}$ tone spread. L tone spread is blocked because the $\mathrm{H}$ tone dominates the stem. The TAM suffix surfaces as $\mathrm{L}$ because it is preceded by a toneless extension and is therefore adjacent to the preceding $\mathrm{H}$ on the tonal tier. It is this derivation that shows the need for $\mathrm{L}$ tone spread to occur before polarity: Inverted rule ordering would produce *[è-kélé ${ }^{\prime}$ sú-ú], as the TAM suffix would erroneously surface $\mathrm{H}$ following the $\mathrm{L}$ tone of the stem.

Figure 11: Imperfective present derivation of trimoraic $/ \mathrm{L}-\mathrm{L}-\varnothing /$ stems

\section{STEM FORMATION}

Root

Add extensions

\section{LEXICAL STAGE}

Add imperfective present TAM prefix

Spreading

Add imperfective present TAM suffix

Polarity
$(\mathbb{H}$

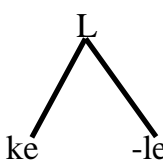

IPR RT EXT

EXT

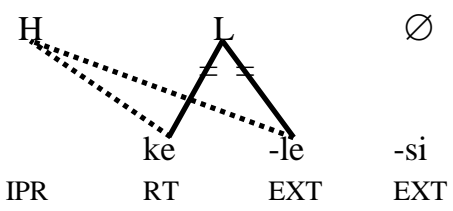

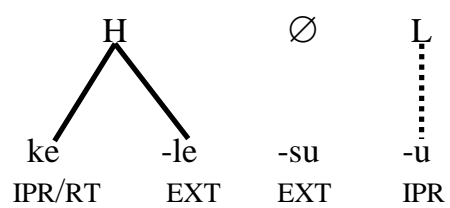


Add $\mathrm{L}$ tone subject pronoun

Default L insertion

Surface form

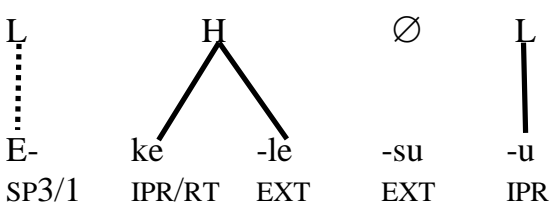

\section{POSTLEXICAL STAGE}

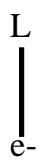

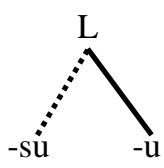

[èkélésùù] 'he/she rinses'

4.3.2 Imperfective past. The imperfective past is framed by a floating /(L)-/ TAM prefix and a toneless segmental TAM suffix [-a]. The floating/(L)-/ spreads rightwards onto the stem until it is blocked by a singly linked $\mathrm{H}$. Evidence is provided in (13), where the left edge of the $\mathrm{H}$ tone stem surfaces as $\mathrm{L}$, even though the $\mathrm{H}$ tone subject pronoun cannot be the source of any $\mathrm{L}$ tone spread.

$13 / \mathrm{H} / / \mathrm{E}^{-} \quad$ (L)- wé -lé -sí $\quad$-ka/ $\rightarrow$ [é- wè -lè -sá -à] 'you (pl) were listening' /É- (L)- kú -ú -dí -ka/ $\rightarrow$ [é- kù -ù -dá -à] 'you (pl) were twisting' SP2PL IPA RT EXT EXT IPA

Moreover, in (14), when the floating L tone spreads rightwards onto the stem until it is blocked by a singly linked H, this creates the HLH sequence necessary for plateauing.

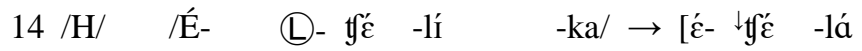

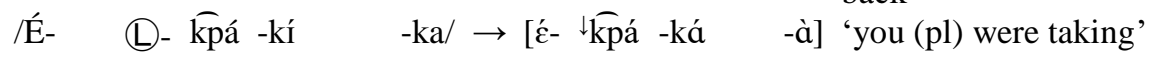

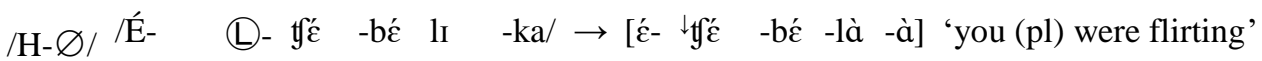

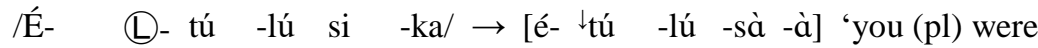

$$
\begin{aligned}
& \text { SP2PL IPS RT EXT EXT IPA } \\
& \text { demolishing' }
\end{aligned}
$$

Figure 12 shows the concatenation of trimoraic $\mathrm{H}$ tone stems with the addition of the $2^{\text {nd }}$ person plural $\mathrm{H}$ tone pronoun to illustrate polarity and $\mathrm{L}$ tone spread.

Figure 12: Imperfective past derivation of trimoraic/H/ stem with $H$ tone subject pronoun STEM FORMATION

Root

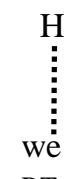


Add extension(s)

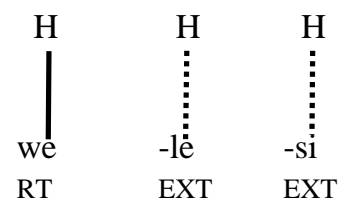

\section{LEXICAL STAGE}

Add imperfective past TAM prefix

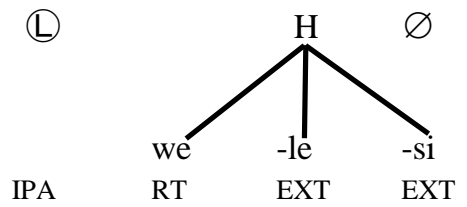

Spreading

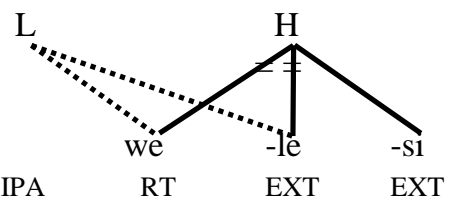

Add imperfective past TAM suffix

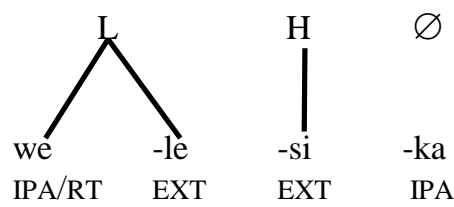

Polarity

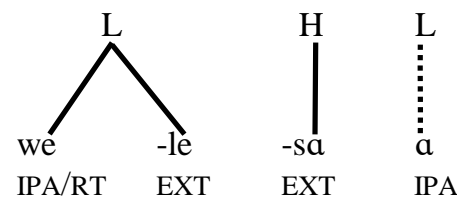

Add $\mathrm{H}$ tone subject pronoun

$\mathrm{H}$
$\vdots$
$\mathrm{E}-$
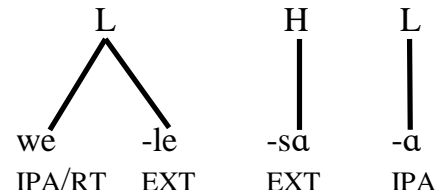

\section{POSTLEXICAL STAGE n/a}

Surface form

[éwèlèsáà] 'you (pl) were listening'

At this point in the analysis, the stray erasure rule (see Section 0) is evoked to account for the lack of downstep in verb forms with dimoraic /H- $\varnothing /$ stems. In Figure 13, the floating /LD-/ tone TAM marker cannot spread, because it is blocked by the singly linked $\mathrm{H}$ on the root. When a floating tone has done all the spreading and merging it can and is left unassociated at the end of the derivation, it is erased. 
Figure 13: Stray erasure in the imperfective past concatenation of dimoraic $/ \mathrm{H}-\varnothing /$ stems STEM FORMATION

Root

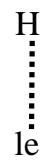

RT

Add extension(s)

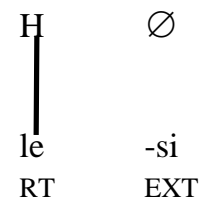

LEXICAL STAGE

Add imperfective past TAM prefix

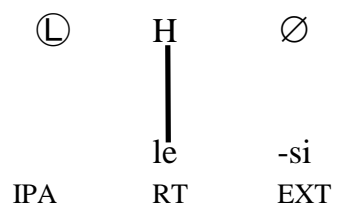

Add imperfective past TAM suffix

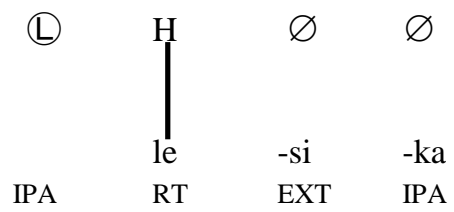

Polarity

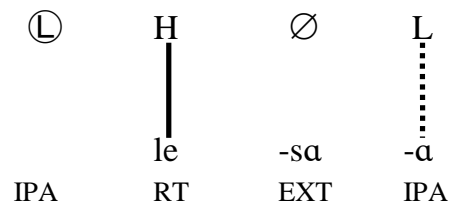

Add $\mathrm{H}$ tone subject pronoun

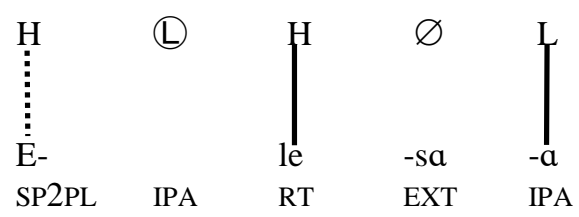


POSTLEXICAL STAGE

Default L insertion

Stray erasure

Surface form
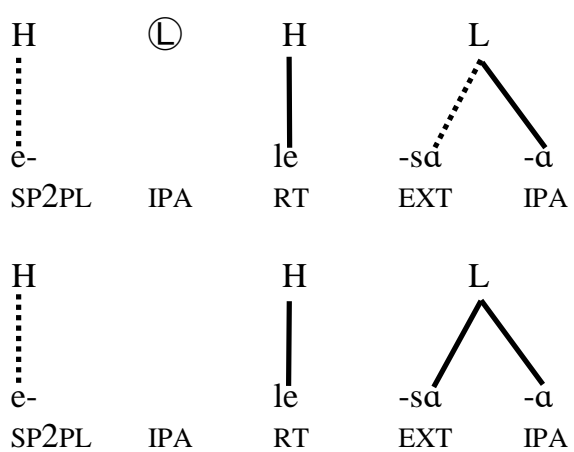

[élésàà] 'you (pl) were losing’ (not *[éłlésàà])

4.3.3 Perfective. The perfective is framed by a zero TAM prefix $/ \varnothing_{-} /$and a toneless segmental TAM suffix /-a/. Evidence for the former is twofold. Firstly, when a $\mathrm{H}$ tone subject pronoun is added to a stem beginning with a $\mathrm{H}$ tone, that tone is unaffected by any intervening element (15).

15 /H-H/ /É-

$$
/ \text { É- }
$$

$$
\varnothing-\quad \text { t'e }{ }^{\prime}-l^{\prime}
$$

/É-

$\varnothing$ - 大pá -kí
$-\mathrm{a} / \rightarrow\left[\varepsilon^{\prime}-\mathrm{t}^{\prime} \dot{\varepsilon} \quad-1 \mathrm{a}\right.$
$-\mathrm{a} / \rightarrow\left[\varepsilon^{\prime}-\widehat{\mathrm{kpa}}-\mathrm{a}\right.$
-a/ $\rightarrow$ [é- kúú -dá

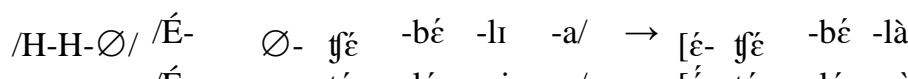
/É-

$\varnothing-$ tu

SP2PL PRF -à] 'you (pl) gave back'

-à] 'you (pl) took'

-à] 'you (pl) twisted'

Secondly, when a L tone subject pronoun is added, it spreads unhindered onto the stem until it is blocked by a singly linked $\mathrm{H}$ (16).

\begin{tabular}{|c|c|c|c|c|c|c|c|c|}
\hline \multirow[t]{3}{*}{ /H-H/ } & /È- & $\varnothing-\mathrm{tg}^{\prime}$ & -lí & & $-a /$ & $\rightarrow[\grave{\varepsilon}-\mathrm{t} \dot{\varepsilon}$ & -lá & -à] 'he/she gave back' \\
\hline & /È- & $\varnothing$ - 大pá & -kí & & $-a /$ & $\rightarrow[\grave{\varepsilon}-\widehat{\mathrm{kpa}}$ & -á & -à] 'he/she took' \\
\hline & /È- & $\varnothing$ - kúú & -dí & & $-a /$ & $\rightarrow$ [è- kùù & -dá & -à] 'he/she twisted' \\
\hline \multicolumn{2}{|c|}{ /H-H-Ø/ /È- } & $\varnothing-\mathfrak{t g}^{\prime}$ & $-b \varepsilon^{\prime}$ & $-1 \mathrm{I}$ & $-a /$ & $\rightarrow[\grave{\varepsilon}-\mathfrak{y} \dot{\varepsilon}$ & -bé -là & -à] 'he/she flirted' \\
\hline & $\begin{array}{l}\text { /È- } \\
\text { SP3s }\end{array}$ & $\begin{array}{l}- \text { tú } \\
\text { F RT }\end{array}$ & $\begin{array}{l}\text {-lú } \\
\text { EXT }\end{array}$ & $\begin{array}{l}-\mathrm{si} \\
\mathrm{EX}\end{array}$ & $\begin{array}{l}-\mathrm{a} / \\
\text { PRF }\end{array}$ & $\rightarrow$ [è- tù & -lú -sà & $\begin{array}{l}\text {-à] 'he/she } \\
\text { demolished' }\end{array}$ \\
\hline
\end{tabular}

16

Figure 14 shows the concatenation of trimoraic $/ \mathrm{H} \varnothing /$ stems to illustrate $\mathrm{L}$ tone spread, polarity and default $\mathrm{L}$ insertion. 
Figure 14: Perfective derivation of trimoraic $/ \mathrm{H} \varnothing /$ stems STEM FORMATION

Root

Add extension(s)

\section{LEXICAL STAGE}

Add perfective TAM prefix

Add perfective TAM suffix

Polarity

Add L tone subject pronoun

Spreading $\varnothing$

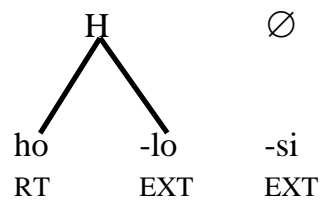

PRF

RT

EXT

$\varnothing$

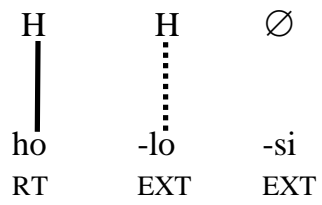

$\varnothing$

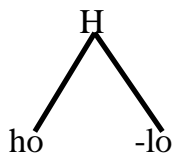

PRF

RT EXT<smiles>[O]</smiles>
$-\mathrm{a}$ $\varnothing$

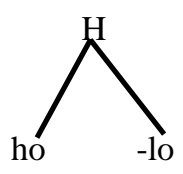

PRF

EXT

$\varnothing$

PRF $\varnothing$

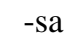

EXT
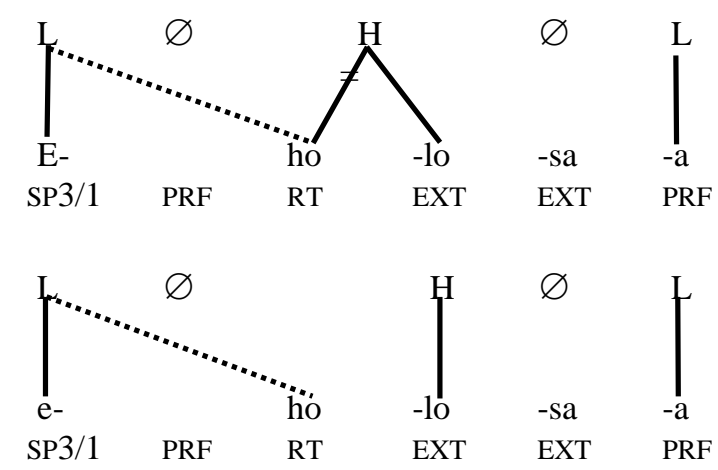


\section{POSTLEXICAL STAGE}

Default L insertion

Surface form
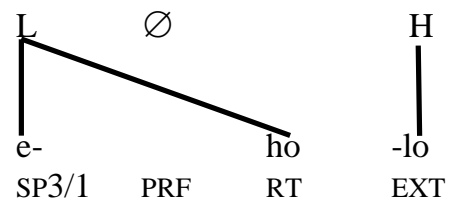

EXT

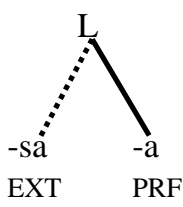

PRF

[èhòlósàà] 'he/she sipped'

4.3.4 Irregular forms. It only remains to account for two kinds of irregularity. The first concerns prefixes whose tones spread across entire words. This is the case with the floating $/(\mathbb{H}-/$ imperfective present TAM prefix in di- and trimoraic $\mathrm{H}$ tone verb stems, where polarity is unexpectedly absent (17):
17 /H/ /È- $\quad(H-$ kó $\quad$-tí $\quad$-kI/ $\rightarrow$ [è- kó -tú $\quad$-ú] 'he/she folds' /È- $\mathbb{A}$ - wé -lé -sí -kI/ $\rightarrow$ [è- wé -lé -sứ -ứl] 'he/she listens' SP3/1 IPR $\quad$ RT $\quad$ EXT $\quad$ EXT $\quad$ IPR
/H/ /É- (H)- kó -tí $\quad$-kI/ $\rightarrow$ [é- kó -tú $\quad$-ú] 'you (pl) fold' /É- (H)- wé -lé -sí -kI/ $\rightarrow$ [é- wé -lé -sứ -ứ] ‘you (pl) listen’ SP2PL IPR RT EXT EXT IPR

Tone spreading across entire words also occurs when the $2^{\text {nd }}$ person plural subject pronoun is added to perfective $\mathrm{L}$ tone stems (18).

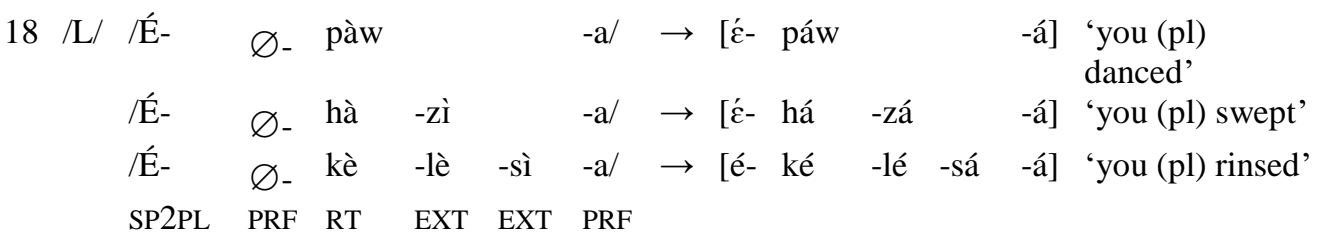

The second kind of irregularity concerns $\mathrm{H}$ tone $\mathrm{CVw}$ verbs. In the perfective, the $\mathrm{L}$ tone of the subject pronoun spreads unexpectedly onto the root even though its tone is singly linked (the TAM suffix surfaces with polar tone as usual) (19).

\begin{tabular}{|c|c|c|c|c|c|c|c|c|c|}
\hline \multirow[t]{4}{*}{19 /H/ } & /È- & $\varnothing-$ & háw & $-\mathrm{a} /$ & $\rightarrow$ & {$[\grave{\varepsilon}-$} & hàw & -á] & 'he/she gave' \\
\hline & /È- & $\varnothing-$ & lów & $-a /$ & $\rightarrow$ & {$[\grave{\varepsilon}-$} & lòw & -á] & 'he/she threw away' \\
\hline & /È- & $\varnothing-$ & náw & $-\mathrm{a} /$ & $\rightarrow$ & {$[\grave{\varepsilon}-$} & nàw & -á] & 'he/she saw' \\
\hline & SP3/1 & PRF & RT & PRF & & & & & \\
\hline
\end{tabular}

A reviewer has queried whether analyzing the /w/ of CVw verbs as a TBU would eliminate this exception. However, if this were the case, the /w/ would surface as a singly linked $\mathrm{H}$ following $\mathrm{L}$ tone spread in (19). Also, the consonants $/ \mathrm{p}, \mathrm{m}, \mathrm{w} /$ form a natural [LABIAL] class that all undergo the same morphophonological processes, so if /w/ were analyzed as a TBU in root final intervocalic position, $/ \mathrm{m} /$ and $/ \mathrm{p} /$ would have to be as well, which is clearly unlikely. It is therefore better to treat the $/ \mathrm{w} /$ as the first constituent in a single tone bearing CV mora along with the following vowel. 
In the same subset of verbs, the Imperfective Past is irregular because the L tone of the TAM suffix spreads leftwards on to the adjacent root tone instead of the L tone of the subject pronoun spreading right $(20){ }^{16}$

20 /H/ /È-

$$
\text { (L)- háw -ka/ } \rightarrow \text { [غ̀- háwà }
$$

-à] he/she was giving

/È-

(L)- lów

$-\mathrm{ka} / \rightarrow[\grave{\varepsilon}-$ lówà

-à] he/she was throwing away

/È-

(L)- náw

$-\mathrm{ka} / \rightarrow\left[\grave{\varepsilon}^{-}\right.$náwà

-à] he/she was seeing

$\mathrm{SP} 3 / 1$

IPA

21 /H/ [É-

$$
\text { [É- }
$$

(L)- háw

$-\mathrm{ka} / \rightarrow\left[\bar{\varepsilon}^{\prime}-\right.$ háwà

-à] you (pl) were giving

[É-

(L)- lów

$-\mathrm{ka} /$

[ć- lówà

-à] you (pl) were throwing away

SP2PL

(L)- náw -ka/

[ć- náwà

-à] you (pl) were seeing

As in the regular forms of the imperfective past (Section 0), it is necessary to evoke stray erasure (Section 0) to explain why there is no downstep in the surface forms of (21). The floating $\mathrm{L}$ tone of the TAM suffix is unable to spread, because it is blocked by the singly linked $\mathrm{H}$ on the root. Then, when it is left unassociated at the end of the derivation, it is erased.

\section{Conclusion}

This paper has provided a revised account of the underlying tone patterns of Kabiye verbs, in which roots are analyzed as $/ \mathrm{H}, \mathrm{L} / \mathrm{while}$ verbal extensions exhibit a $/ \mathrm{H}, \mathrm{L}, \varnothing /$ ternary contrast. Underspecification resolves an adjacency issue in surface HL stems with regard to suffix polarity. Table 9 summarizes the derivational and inflectional affixes.

\begin{tabular}{|c|c|c|c|}
\hline & & Prefix & Suffix (toneless) \\
\hline \multirow[t]{4}{*}{ Derivations } & Singular adjectives $(\mathrm{cl} .1,3)$ & $/ \mathrm{k} \hat{\mathrm{I}}-/$ & /-U/ \\
\hline & Singular adjectives (cl. 5) & $/ \mathrm{k} \hat{\mathrm{I}}-/$ & /-yE/ \\
\hline & Singular adjectives (cl. 12) & $/ \mathrm{k} \hat{\mathrm{I}}-/$ & /-ka/ \\
\hline & Locative nominalizations (cl. 5) & $/ \mathrm{tII}-/$ & /-yE/ \\
\hline \multirow[t]{3}{*}{ Inflections } & Imperfective present & / $\mathbb{H}-$ / & /-kI/ \\
\hline & Imperfective past & / (L) -1 & /-ka/ \\
\hline & Perfective & $1 \varnothing-1$ & $/-\mathrm{a} /$ \\
\hline
\end{tabular}

Table 9: Derivational and inflectional affixes

In the derivational forms, adjectives are framed by a /HL/ prefix and a toneless suffix, the segments of which vary according to the (singular) noun class. Locative nominalizations are framed by a /L/ prefix and a class 5 toneless suffix. In both cases, the $\mathrm{L}$ of the prefix spreads onto the root or stem until it is blocked by a singly linked $\mathrm{H}$.

As for inflectional forms, floating tone prefixes exhibit a second $/ \mathrm{H}, \mathrm{L}, \varnothing /$ ternary contrast. The floating / $(\mathbb{H}-/$ tone imperfective present TAM prefix spreads rightwards onto the root and blocks $\mathrm{L}$ tone spread of the subject pronoun. The floating /(L)-/ tone imperfective past TAM prefix pre-

\footnotetext{
${ }^{16}$ The epenthetic vowel following a root final [LABIAL] consonant is unique to the imperfective past. The juxtaposed [DORSAL] consonants /wk/ elide but retain their [DORSAL] feature in the long back unrounded vowel.
} 
empts $\mathrm{L}$ tone spread of the subject pronoun. The zero tone $/ \varnothing-/$ of the perfective TAM prefix permits $\mathrm{L}$ tone spread of the subject pronoun.

This account of tonal processes in Kabiye derivational and inflectional forms neatly dovetails with a previous account of the associative noun phrase (Roberts 2003). In all three syntactic environments, the L tone of any prefix spreads rightwards onto the root until it is blocked by a singly linked $\mathrm{H}$, stray erasure accounts for the lack of downstep in certain forms, and HLH plateauing occurs wherever the condition is met. ${ }^{17}$

\section{Abbreviations}

$\begin{array}{ll}\text { ADJ } & \text { adjective } \\ \text { ADV } & \text { adversative } \\ \text { AOR } & \text { aorist } \\ \text { C } & \text { consonant } \\ \text { CL } & \text { noun class } \\ \text { EXT } & \text { verbal extension } \\ \text { H } & \text { H tone } \\ \text { HAB } & \text { habitual } \\ \text { IMP } & \text { imperative } \\ \text { IPA } & \text { imperfective past } \\ \text { IPR } & \text { imperfective present } \\ \text { L } & \text { L tone } \\ \text { N } & \text { nasal } \\ \text { NEG } & \text { negative } \\ \text { NOM } & \text { nominalizer } \\ \text { OP } & \text { object pronoun } \\ \text { OWN } & \text { ownership } \\ \text { PRF } & \text { perfective } \\ \text { PL } & \text { plural } \\ \text { PP } & \text { possessive pronoun } \\ \text { PX } & \text { prefix } \\ \text { PT } & \text { root } \\ \text { SG } & \text { singular } \\ \text { SP } & \text { subject pronoun } \\ \text { ST } & \text { stem } \\ \text { SX } & \text { noun class suffix } \\ \text { TAM } & \text { tense, aspect, mood } \\ \text { V } & \text { vowel } \\ & \\ & \end{array}$

\footnotetext{
${ }^{17}$ This article has its origins in my Masters dissertation undertaken at the Université de la Sorbonne Nouvelle, Paris III in 2001-2003 and presented orally at the 24th West African Linguistics Conference, University of Ibadan, Nigeria in 2004. I would particularly like to express my thanks to my Masters supervisor, Annie Rialland, for being the first to suggest, many years ago, that Kabiye might warrant an underspecification analysis. I also wish to acknowledge my debt to the following people for their helpful comments during the preparation of this published version: Colleen Ahland, Mike Cahill, Rod Casali, Nick Clements, Jonathan Evans, Larry Hyman, David Odden, Cédric Patin, Mary Pearce, Cécile Padayodi, Steve Parker and Keith Snider and three anonymous reviewers. I am also indebted to my informants, without whom this research would never have been completed: †Emmanuel Pidassa, Essodina Pidassa, Jonas Pidassa, Mauril Sodiyo and †Hénok Tchinguilou.
} 


\section{References}

Akinlabi, Akinbiyi \& Mark Liberman. 2000. Tonal complexes and tonal alignment. Paper presented at the Tone Symposium, University of Tromsø.

Akumbu, Pius W. 2011. Tone in Kejom (Babanki) associative construction. Journal of West African Languages 38:1.1-20.

Anttila, Arto \& Adams Bodomo. 2000. Tonal polarity in Dagaare. In Vicki Carstens \& Frederick Parkinson (eds.), Advances in African Linguistics. Proceedings of the 28th Annual Conference on African Linguistics at Cornell University, 119-134. Trenton NJ: Africa World Press.

Baloubi, Désiré (2005). The morphophonemics of the Idaacha dialect of Yoruba. Charlotte, NC: Conquering Books.

Buckley, Eugene. 1991. Low-tone spreading in Chalcatongo Mixtec. In (ed.) James E. Redden, Occasional Papers on Linguistics: Papers from the American Indian Languages Conferences held at the University of California, Santa Cruz, July and August 1991, 168172. Carbondale, IL: Department of Linguistics, Southern Illinois University.

Carvalho, Fernando O. 2014. Notes on underspecification and reversal in Kimbundu tonology. Cologne: Afrikanistik Aegyptologie Online.

Chirkova, Katia \& Alexis Michaud. 2009. Approaching the prosodic system of Shixing Language and Linguistics 10:3.

CLNK. 1999. Tom kpou kabıye-fransıl (Dictionnaire kabiyè-français). Lomé: Ministère de l'Éducation Nationale et de la Recherche, Comité de Langue Nationale Kabiyè et SILTogo.

Creissels, Denis. 2021. Morphology in Niger-Congo languages, The Oxford encylopedia of morphology. Oxford: Oxford University Press.

Daly, John P. \& Larry Hyman. 2005. On the representation of tone in Peñoles Mixtec. UC Berkeley Phonology Lab Annual Report (submitted to IJAL).129-162.

Delord, Jacques. 1976. Le kabiyè. Lomé: lnstitut national de la recherche scientifique.

Dicanio, Christian T. n.d.. The structure of the Itunyoso Trique word. Lyon: Laboratoire Dynamique du Langage CNRS Université Lyon-2.

Finney, Malcolm A. 2002. Compounding and reduplication in Krio. Journal of West African Languages 29:2.23-34.

Garber Kompaoré, Anne. 1987. A tonal analysis of Senufo: Sucite dialect. Illinois IL: University of Illinois at Urbana-Champaign. PhD dissertation.

Goldsmith, John. 1976. Autosegmental and metrical phonology: MIT. PhD dissertation. Published by Blackwell, Oxford 1990.

Gope, Amalesh \& Shakuntala Mahanta. 2016. Polarization and tonal dissimilation: a case of Sylheti suffixation. Paper presented at the 3rd Workshop on Tone and Intonation, 7-8 January 2016, Indian Institute of Technology, Guwahati, India.

Halme, R. 2004. A tonal grammar of Kwanyama. Cologne: Rüdiger Köppe.

Harry, Otelemate \& Larry Hyman. 2014. Phrasal construction tonology: the case of Kalabari. Studies in Language 38:4.649-689.

Hyman, Larry. 1993. Structure preservation and postlexical tonology in Dagbani. In Sharon Hargus \& Ellen M. Kaisse (eds.), Studies in Lexical Phonology, 235-254. San Diego, CA: Academic Press.

Hyman, Larry. 2001. Privative tone in Bantu. In (ed.) Shigeki Kaji, Cross-linguistic studies of tonal phenomena, 237-257. Tokyo: Institute for the Study of Languages and Cultures.

Hyman, Larry. 2007. Universals of tone rules: 30 years later. In Tomas Riad \& Carlos Gussenhoven (eds.), Tones and tunes: Studies in word and sentence prosody, 1-34. Berlin: Mouton de Gruyter.

Hyman, Larry. 2009. The representation of tone. UC Berkeley Phonology Lab Annual Report.108132. 
Hyman, Larry. 2013. Towards a Typology of Postlexical Tonal Neutralizations. Paper presented at the International Conference on Phonetics and Phonology, National Institute for Japanese Language and Linguistics, Tachikawa, Japan.

Hyman, Larry \& R. Schuh. 1974. Universals of tone rules: Evidence from West Africa. Linguistic Inquiry 5.81-115.

Inkelas, Sharon. 1995. The consequences of optimization for underspecification. In J. N. Beckman (ed.), NELS 25: Proceedings of the North East Linguistics Society, 287-302. Amherst, MA: Graduate Linguistic Student Association, Department of Linguistics, University of Massachusetts.

Itô, Junko. 1988. Syllable theory in prosodic phonology. New York, NY: Garland.

Kassan, Balaïbaou Badameli. 1996. Système verbal et énonciation en kabiyè. Paris: Université de la Sorbonne Nouvelle, Paris III. Thèse de doctorat.

Kenstowicz, Michael, Emmanuel Nikiema \& Meterwa Ourso. 1988. Tonal polarity in two Gur languages. Studies in the Linguistic Sciences 18:1.77-103.

Kiparsky, Paul. 1982. Lexical phonology and morphology. In I.S. Yang (ed.), Linguistics in the Morning Calm, 3-91. Seoul: Hanshin.

Lébikaza, Kézié. 1999. Grammaire kabiyè: une analyse systématique - phonologie, tonologie et morphosyntaxe. Cologne: Rüdiger Köppe.

Lee, Seunghun J. 2013. Tonal polarity and paradigm uniformity in the nominal paradigm of Xitsonga (S53). Studies in Phonetics, Phonology and Morphology 19:1.107-123.

Levergood, Barbara. 1987. Topics in Arusa phonology and morphology. Austin, TX: University of Texas.

McCarthy, J. J. 1979. Formal problems in Semitic phonology and morphology. Cambridge, MA: MIT. PhD dissertation. Distributed by Indiana University Linguistics Club. Published by Garland Press, New York, NY, 1985.

McKendry, Inga. 2013. Tonal Association, Prominence and Prosodic Structure in South-eastern Nochixtlán Mixtec. Edinburgh: University of Edinburgh. PhD thesis.

McPherson, Laura. 2012. Tonal underspecification and interpolation in Tommo So (Dogon, Mali). In Jaehoon Choi (ed.), Proceedings of the 29th West Coast Conference on Formal Linguistics, 169-177. Somerville, MA: Cascadilla Proceedings Project.

Melick, Christina. 2012. Tone in the Mbelime verb system. Dallas, TX: SIL International. https://togo-benin.sil.org/resources/archives/51670 (accessed 9 February 2021).

Miehe, Gudrun \& Kerstin Winkelmann (eds.) 2007. Noun class systems in Gur languages, volume 1: South-western Gur languages (without Gurunsi) (Gur Monographs / Monographes voltaïques 9). Cologne: Rüdiger Köppe.

Mohanan, Karuvannur Puthanveettil. 1982. Lexical Phonology. Cambridge, MA: MIT.

Morton, Deborah. 2014. The Temporal and Aspectual Semantics and Verbal Tonology of Gisida Anii. Columbus OH: Ohio State University. PhD dissertation.

Mutaka, Ngessimo M. 1994. The lexical tonology of Kinande. Munich: Lincom Europa.

Myers, Scott. 1998. Surface underspecification of tone in Chichewa. Phonology 15:3.367-391.

Odden, David. 1990. Tone in the Makonde dialects. Studies in African Linguistics 21:1.62-105.

Odden, David. 1994. Adjacency patterns in phonology. Language 70:2.289-330.

Odden, David. 2019. Tone. In Mark Van de Velde \& Koen Bostoen (eds.), The Bantu Languages, 2nd edition. London: Routledge.

Padayodi, Cécile M. 2010. A revised phonology of Kabiye segments and tones. Arlington, TX: University of Texas at Arlington. PhD dissertation.

Parker, Stephen. 1999. A sketch of Iñapari phonology. International Journal of American Linguistics 65:1.1-39.

Paster, Mary \& Yuni Kim. 2011. Downstep in Tiriki. Linguistic discovery 9:1.71-104.

Philippson, Gérard 1998. Tone reduction vs metrical attraction in the evolution of Eastern Bantu tone systems. In Larry Hyman \& Charles Kisseberth (eds.), Theoretical aspects of Bantu tone, 315-329. Stanford: CSLI. 
Picanço, Gessiane. 2005. Mundurukú: Phonetics, phonology, synchrony, diachrony. Vancouver: University of British Columbia. PhD dissertation.

Plunkett, Gray. 2009. An overview of Foodo, a linguistic island in Benin. Journal of West African Languages 36:1-2.107-137.

Pulleyblank, Douglas. 1986. Tone in lexical phonology. Dordrecht: Reidel.

Roberts, David. 2002. Les classes tonales du verbe en kabiyè. Paris: Institut de linguistique et phonétique générales et appliquées, Université de la Sorbonne nouvelle, Paris III. Mémoire de maîtrise.

Roberts, David. 2003. Tone spreading in the Kabiye associative noun phrase. Cahiers voltaïques / Gur Papers 6.95-100.

Roberts, David. 2016. Word tone and tonal overwriting in Kabiye nouns. Journal of African Languages and Linguistics 37:1.131-160.

Roberts, David. 2019. The tone of Kabiye verbal extensions. Journal of West African Languages 46:2.1-28

Roberts, James. 2017. Downstep in Akaselem. Paper presented at the 47th Colloquium on African Languages, Leiden, Netherlands.

Schadeberg, Thilo C. 1989. Tone and history of Nyamwezi verb forms with complex final tones. Afrika und Ubersee 72:1.33-42.

Schwarz, Anne. 2001. Low tone spreading in Buli. Cahiers voltaïques / Gur Papers 6.121-130.

Snider, Keith. 2018. Tone analysis for field linguists. Dallas, TX: SIL International.

Stanley, Richard. 1967. Redundancy rules in phonology. Language 43.393-436.

Steriade, Donca. 1982. Greek prosodies and the nature of syllabification. Cambridge, MA: MIT. Doctoral dissertation.

Stevick, Earl W. 1969. Tone in Bantu. International Journal of American Linguistics 35.330-341.

Tchagbale, Zakari. 2002. L'accent tonal du Tem. In Ulrike Gut \& Dafydd Gibbon (eds.), Proceedings of the conference Typology of African Prosodic Systems, 18-20 May 2001, 25-148. Bielefeld: University of Bielefeld.

Trommer, Jochen. 2005. Polar tone in Kanuri. Unpublished manuscript. Leipzig: University of Leipzig.

Voll, Rebecca. 2012. Tonal variation in the tense system of Mundabli, western Beboid (bantoid, Cameroon). In Matthias Brenzinger \& Anne-Maria Fehn (eds.), Proceedings of the 6th World Congress of African Linguistics, 533-544. Cologne: Rüdiger Köppe.

Williams, Cindy. 2004. An analysis of Amuzgo nominal tone. In (eds) Rosemary Beam de Azcona \& Mary Paster, Report 13: Survey of Californian and other Indian languages. Conference on Otomanguean and Oaxacan languages, 147-161. Berkeley, CA.

Wolff, Ekkehard \& Hassana Alidou. 1989. Desegmentalizaion and tone in Tubu: 'definite marking int he Daza dialect of Tasker. Journal of West African Languages 19:2.27-73.

Zimmermann, Eva. 2016. Tone features and underspecification: morphological H-tone Macuiltianguis Zapotec. Paper presented at the CLS 52, Chicago.

David Roberts <rbrdvd@gmail.com>

Cornwall. UK 